\title{
Bank relationships: effect on the availability and marginal cost of credit for firms in Argentina
}

November 2001

\author{
Jorge M. Streb, Javier Bolzico, Pablo Druck, \\ Alejandro Henke, José Rutman, and Walter Sosa Escudero ${ }^{* * * *}$
}

\begin{abstract}
The paper provides evidence on what affects at the margin the cost and availability of bank credit for firms in Argentina. We study in particular how banks use different pieces of private and public information to screen firms and overcome informational asymmetries in the credit market. Some private information is transferable, like balance sheet data. Private information generated in relationships is not. To capture the closeness of bank relationships, we resort to the concentration of bank credit and the number of credit lines in a bank. We also consider public information available in the Central de Deudores.

The cost of credit is measured using overdrafts, the most expensive line of credit, at the bank that charges the highest rate for overdrafts. We find that the cost of credit is smaller for a firm with a close relationship to the marginal bank. Firms with large assets, a high sales/assets ratio, and a low debt/assets ratio pay a lower interest rate at the margin. A good credit history (no debt arrears and no bounced checks) and collateral also reduce the marginal interest rate.

The availability of credit is measured by unused credit lines as a proportion of total liabilities with the main bank. The availability of credit depends positively on a close relationship with the main bank. Large assets, a high return over assets, a high sales/assets ratio, a low debt/assets ratio, a good credit history, and collateral lead to higher credit availability. Our measure of unused credit lines is less ambiguous than traditional measures like leverage, which may indicate financial distress rather than availability of credit.
\end{abstract}

JEL: D82, E44, G14, G20

\footnotetext{
* The Centro de Economía Aplicada of Universidad del CEMA (UCEMA) and the Banco Central de la República Argentina (BCRA) jointly undertook the project, as part of the Inter-American Development Bank (IADB) Research Network Project 'Determinants and Consequences of Financial Constraints Facing Firms in Latin America and the Caribbean'. Pablo Druck and Jorge Streb are at UCEMA. Alejandro Henke and José Rutman are at the BCRA, but the viewpoints expressed here do not necessarily represent the position of the BCRA (Javier Bolzico was also at the BCRA when the project got started). Walter Sosa Escudero is an invited researcher from the Universidad Nacional de La Plata (UNLP).

${ }^{* *}$ We thank very specially Carlos A. Rodríguez, Director of this project. Miguel Crivelli and Julián Cristiá provided excellent research assistance. We are grateful to Karina Manzaraz for building the database, to Liliana Castiñeira and Verónica Balzarotti for helping to interpret the data, and to Silvina Rodríguez and Marta Cao for conducting an inquiry on how financial institutions reported interest rates to the BCRA. We appreciate the suggestions made by Ricardo Caballero, José Fanelli, Daniel Oks, Eduardo Siandra, and participants of seminars at the IADB, UCEMA, and the 2001 meetings of the Banco Central del Uruguay, LACEA and the AAEP. Arturo Galindo, Fabio Schiantarelli, and Sergio Schmukler made extensive and insightful comments that helped to reshape the whole paper.
} 


\section{Contents}

1. Introduction

2. Conceptual framework

2.1 Theoretical literature

2.2 Empirical evidence

3. Dataset

3.1. Assets of firms

3.2 Bank liabilities

3.3. Interest rates on loans

3.4 Marginal cost of credit 12

3.5 Access to additional credit 13

3.6 Bank relationships 15

4. Econometric evidence 16

$\begin{array}{ll}4.1 \text { Overdraft rate at marginal bank } & 17\end{array}$

4.2 Leverage 23

4.3 Proportion of unused credit lines in main bank 26

4.4 Economic significance $\quad 32$

5. Implications of this study 34

Bibliography $\quad 36$

Appendix $\quad 38$

A. Validation of financial statements of firms $\quad 38$

B. Validation of interest rates 43

C. Classification of credit situation $\quad 45$

D. Definition of variables 46

E. Selection equations in Heckman two-step procedure $\quad 48$ 


\section{Tables}

1. Assets of firms in complete sample 9

2. Assets of firms in reduced sample 9

3. Relation between assets and bank liabilities $\quad 10$

4. Breakdown of bank liabilities $\quad 10$

5. Breakdown of loans 11

6. Breakdown of unused credit lines 11

7. Interest rates in validated sample 12

$\begin{array}{ll}\text { 8. Maturity by loan type } & 13\end{array}$

9. Overdrafts drawn by credit situation 14

10. Unused credit lines by credit situation $\quad 15$

11. Bank relationships by size of liabilities 16

12. Interest rate regressions: Different sub-samples 19

13. Interest rate regressions: Additional variables 22

14. Debt-ratio regressions 24

15. Unused credit ratio regression equations: Different sub-samples 28

16. Unused credit ratio regression equations: Additional variables 31

17. Effect of number of banks on credit availability 32

18. Economic significance of variables affecting credit availability 33

19. Economic significance of variables affecting cost of credit 34

A1. Elimination of duplicate registers 39

A2. Validation criteria $\quad 40$

A3. Balance sheets with zero's 41

A4. Debt/assets 41

A5. Return on assets $\quad 42$

A6. Balance sheet frequency $\quad 42$

A7. Balance sheet dates 43

B1. Interest rates reported in October 2000

C1. Credit situation $\quad 45$

C2. Maximum differences in reported credit situation 45

D1. Definitions of variables in price regressions 46

$\begin{array}{ll}\text { D2. Definitions of variables in quantity regressions } & 47\end{array}$

E1. Unused credit ratio selection equations: Different sub-samples $\quad 48$

E2. Unused credit ratio selection equations: Additional variables 49 


\section{Introduction}

This paper tries to evaluate the determinants of the variation in the cost and availability of bank credit across firms in Argentina. This issue has a high profile because many firms complain loudly about bank credit being too expensive. There is also widespread complaint about limited access to bank credit. These same complaints are voiced in many places, but in Argentina this happens against the backdrop of underdeveloped financial markets, not only compared to OECD countries, but also to emerging countries like Chile (Caballero, 2000). Stock market capitalization is low, and so is financial intermediation in terms of the ratio of M3 to GDP, or of loans to the private sector to GDP. To complete this picture, in the last two years high country risk, and crowding out by the public sector, have made the problem of credit constraints particularly acute for firms in Argentina.

To study credit constraints, a cross-section for October 2000 is built with data collected by the Banco Central de la República Argentina (BCRA) from financial institutions. All financial institutions supervised by the central bank are referred to as "banks" for short. Bank credit is particularly relevant for firms in Argentina. Mayer (1994) defines as a banking economy a country with a small proportion of quoted firms, and as a market economy a country with a high percentage of quoted firms. Argentina can clearly be classified as a banking economy, because less than a hundred firms are quoted in the stock exchange, whereas the financial system grants credit to over a hundred thousand legally incorporated firms.

The theoretical literature on credit constraints emphasizes the importance of information problems. Our goal is to see how different bits and pieces of information affect the cost and access to credit. In Argentina, the changes in this front have been substantial. There was practically no credit market in 1990. Banks had imploded, and the little assets they had were concentrated in government securities. After the Convertibility plan was launched in 1991 with the aim of achieving price stability, lending to firms had to start almost from scratch. Since it takes time to generate a track record to evaluate firms, it seems no wonder that firms should initially have been subject to large individual credit constraints. Besides this internal information of banks, which can be termed relationships, private credit bureaus and public credit registers developed during the 90's, pooling part of this internal information.

In the empirical literature there is no straightforward procedure to detect the presence of credit constraints. Usually, the presence of credit constraints is detected indirectly, e.g. by the excess sensibility of investment to liquidity (cf. Schiantarelli, 1996). This paper proposes a different approach to analyze credit constraints. This approach is closest in spirit to Petersen and Rajan (1994), who try to detect the presence of credit constraints by the degree that firms resort to trade credit to finance their operations. We propose to look instead at the lack of unused credit lines as an indicator of credit constrained firms. Our study can throw light on the intensive credit margin, which has to do with how much credit is available to a firm that already operates with the financial system. Since we do not have data on firms that have not received any credit from the financial system, the paper cannot explain extensive credit margins that determine whether a firm is cut off from bank loans or not.

Our main findings are as follows. The availability of credit depends positively on close relationships with a bank. Good characteristics of a firm (large assets, a high return over assets, a high sales/assets ratio, and a low debt/assets ratio), a good credit history (normal credit situation and no bounced checks) and collateral also lead to higher credit availability. Significantly, a good median credit situation in the public credit register leads to higher credit availability, 
suggesting that the Central de Deudores eases credit constraints for good firms. As to the cost of credit, the findings mostly parallel those of credit availability. The cost is smaller for a firm with a close relationship to a bank. Firms with large assets, a high sales/assets ratio, and a low debt/assets ratio pay a lower interest rate (returns over assets, however, turn out not to be significant). A good credit history and collateral also reduce the interest rate.

An important difference between the effects on the price and the quantity of credit is that the interest rate does not increase monotonically as the credit situation deteriorates, unlike credit availability that decreases monotonically. Similarly, the median credit situation in the public credit register does not affect the cost. These findings are consistent with credit rationing, which predicts that beyond a certain point it makes no sense for the lender to raise interest rates because that only increases the probability of default. Rather, as risk rises, lenders will cut back credit.

The paper proceeds as follows. Section 2 places our approach on how public and private information impacts the market for bank loans in the context of the existing literature on the topic. Section 3 describes the dataset constructed to characterize the workings of the loan market for firms in Argentina. Section 4 presents our regressions on the cost of credit and the access to credit at the margin. Section 5 presents the conclusions, as well as suggestions for further work.

\section{Conceptual framework}

We briefly review the theoretical literature on the role of information in credit markets, and previous empirical studies on how it affects the cost and access to credit of firms.

\subsection{Theoretical literature}

Informational asymmetries are a central issue in credit markets. Freixas and Rochet (1997) distinguish between three settings of asymmetric information: ex-ante asymmetric information (adverse selection), interim asymmetric information (moral hazard), and ex-post asymmetric information (costly state verification model, that can be related to ex-post moral hazard).

In the theoretical literature, asymmetric information has been identified as the source of equilibrium credit rationing. Asymmetric information pushes the market away from that of a perfectly competitive equilibrium where the intersection of demand and supply clear the market. The classic contribution by Stiglitz and Weiss (1981) predicts that a lender's expected return on a risky loan is a non-monotonic function of the interest rate. This can be due either to adverse selection, because as interest rates rise the best borrowers drop out, or to moral hazard, because at higher interest rates borrowers adopt riskier strategies. Hence, lenders may not be willing to supply more credit beyond a certain interest rate. This may lead to a credit rationing equilibrium, where borrowers are willing to demand more than they are supplied at the equilibrium interest rate. This type of credit rationing is an intensive limit, or type 1 credit rationing. If lenders refuse outright to supply any loans at all to some of the prospective customers at the prevailing interest rate, the borrower faces instead an extensive limit, or type 2 credit rationing. This is for example the case in the costly state verification version of credit rationing in Williamson (1987).

To alleviate the degree of asymmetric information, banks resort to different mechanisms. Banks are precisely the organizations that specialize in recollecting information on potential borrowers, to price credit risks appropriately. ${ }^{1}$ A common practice by banks is to implement screening mechanisms (alternatively, good firms have an incentive to signal their type, in order to differentiate themselves from bad firms and get better terms on their loans). Another response

\footnotetext{
${ }^{1}$ Banks can also be important to monitor borrowers, solving corporate governance problems related to moral hazard (cf. Allen, 2001).
} 
to the problem of asymmetric information is the development of private information through banking relationships.

In this regard, Petersen and Rajan (1994) distinguish between public and private information in lending activities. Private information is the information that lenders acquire in the course of relationships with borrowers, information that is not easily transferable to others. In this same line, Berger, Klapper, and Udell (2000) contrast relationship lending to pure transactions lending. Relationship lending is based on information gathered by the lender through contact over time with the firm, its owner, and the local business community. Pure transactions lending is based on information from financial statements, credit scoring and other similar quantitative techniques. This information is relatively public and transparent, and only requires the analysis of currently available data.

The idea of relationship lending is already in Akerlof (1970), in his example of local moneylenders in credit markets in India who can profitably lend because of their knowledge of local borrowers' creditworthiness. Outside middlemen trying to arbitrage in that market, lending at the same high rates, would lose money due to the risk of attracting borrowers with poor repayment prospects. The emergence of financial intermediaries such as banks can thus be explained as a way to solve the problem of asymmetric information in financial markets.

Relationship information is especially important for small firms. Small firms produce less public information than large firms, which can instead resort directly to capital markets to place debt (Diamond, 1991). Relationships affect the bank-firm interaction in at least two dimensions. Concerning the amount of credit, Diamond (1984) shows that relationships allow a firm to have more access to credit. With respect to the cost of credit, there is no clear-cut association between interest rates and relationships. On the one hand, Diamond (1984) shows that a relationship with a single bank may reduce risk, leading to a lower interest rate charged. The reduction in interest rates is due both to the monitoring role of the bank, that reduces the incidence of moral hazard, and to an improved knowledge of the firm, that helps to overcome the problem of adverse selection. On the other hand, relationships provide a bank with an informational advantage. This information gives the bank market power over the firm, allowing it to increase the interest rate charged. In this context, Sharpe (1990) claims that by extending its financial relationships to more banks, a firm can avoid to pay its main bank an informational rent. Summarizing, there are theoretical justifications for both an increase and decrease of a firm's interest rate with closer relationships.

Whether other information is either private or public depends on the regulations in place, like laws of habeas data that guarantee privacy. Public credit registers and private credit bureaus that pool the information of lenders allow a reduction of the degree of asymmetric information. Since information is costly to produce, other lenders might have an incentive to free ride and compete away the banks' best clients if it becomes public information, which may reduce the incentives of banks to invest in relationship lending in the first place. While this may be the case for positive information on borrowers, negative information helps to discipline borrowers, reducing problems of moral hazard.

Asymmetric information and agency problems are not the only source of credit market imperfections. For example, an inefficient legal system may diminish the value of collateral, leading to a credit constrained equilibrium where firms cannot carry out all their worthwhile investment opportunities despite the guarantees they can provide. Even if there is no credit 
rationing, because interest rates rise to clear the market, firms suffer from credit constraints due to these inefficiencies. These problems can contribute to weak international financial links and an underdeveloped domestic financial market (Caballero and Krishnamurthy, 1999).

\subsection{Empirical literature}

Much of the literature on credit constraints faced by firms focuses on its effects on investment, which can be detected through the excess sensitivity of investment to liquidity (Schiantarelli, 1996, provides a survey of this literature). There is also a specific literature that looks at how bank relationships can contribute to ease liquidity constraints faced by firms. Hoshi, Kashyap and Scharfstein (1990), for instance, look at the associations of firms with banks in Japan, showing that the benefit of bank association for Japanese firms is that it reduces the excess sensitivity of investment to cash flow in times of financial distress.

We follow a different tack. Our approach resembles Petersen and Rajan (1994) in that we try to look more closely at the issue of credit availability in itself. The key insight in Petersen and Rajan is that the use of trade credit can be an indication of credit constraints. In their study of small business firms in the U.S., the average rate on bank loans is $1 \%$ per month, or $12 \%$ per year. They calculate that firms that do not take discounts for early payment forsake a $2 \%$ discount to stretch the payment period 20 days more, equivalent to a $3 \%$ monthly interest rate, or a 44\% annual interest rate. Accordingly, they use the percentage of discounts taken for early payment as an indication of firms that do not face credit constraints, because they have access to cheaper credit from the financial system. Conversely, the percentage of trade credit paid late is an indication of credit constrained firms.

If trade credit discounts taken is an indirect indicator of credit availability in banks, an alternative is to try to assess credit availability in banks directly. This is meaningful if line of credit contracts, or loan commitment contracts, are an important source of loans. Melnik and Plaut (1986) state that loan commitment contracts are behind more than $70 \%$ of commercial and industrial loans in the U.S. They study the ex-ante tradeoffs between size of loan commitments, and other variables such as interest rate premium charged, and collateral offered. Since they concentrate on the ex-ante determinants of lines of credit contracts, Melnik and Plaut provide no evidence on credit constraints per se. They do mention that credit constraints can be interpreted as the ex-post usage of credit beyond these loan commitment contracts, when firms have to turn to spot loans at higher rates.

Putting together the approaches in Petersen and Rajan (1994) and Melnik and Plaut (1986), we propose the unused portion of pre-committed credit lines as a measure of firms that are not credit constrained. Unused credit lines can be interpreted as an intensive, not an extensive, measure of credit constraints. An extensive credit constraint is the case when no bank is willing ex-ante to sign a line of credit contract with a firm. All the firms in our sample have bank credit, so they do not face this type of constraint (except a few firms in our sample that only have write-offs). However, even those firms that are given a credit line face a maximum credit limit or commitment. This limit is potentially an intensive credit constraint. Firms that ex-post have unused credit lines are not credit constrained, but the lack of unused credit lines may provide direct evidence on firms that face intensive credit constraints. We also believe that unused credit lines may be a less ambiguous measure of credit availability than total debt figures that are often used in the literature. 
As to the effect of banking relationships on access to credit, Petersen and Rajan (1994) show how their measures of lending relationships are related to less reliance on trade credit. They interpret this in the sense that firms with closer relationships face less credit constraints, having more access to cheaper bank credit. Later studies also find that relationships lead to more access to credit, using different measures of credit availability. Cole (1998) finds that a potential lender is more likely to extend credit to a firm with which it has a pre-existing relationship. Machauer and Weber (2000) find that a firm obtains a higher proportion of financing from a bank with which it has a closer relationships, using as dependent variable the ratio of the total credit line at each bank relative to the total assets of the firm.

In relation to the effects of relationships on the cost of credit, using the interest rate paid on the last loan of each firm, Petersen and Rajan find that lending relationships affect the quantity of credit more than they affect the cost of credit. Their measure of number of banks, that signals a weaker relationship, is related to a higher cost of credit, but the length of the relationship does not affect interest rates at all. On the contrary, also using the interest rate paid on the last loan, Berger and Udell (1995) find that borrowers with longer banking relationships pay lower interest rates. However, they restrict their analysis to lending under lines of credit. A recent study by D'Auria, Foglia and Marullo-Reedtz (1999) establishes that close relationships reduce the interest rate a firm is charged on uncollateralized overdraft facilities, using as a proxy of close relationships the share of each bank over the total credit lines granted by the banking system to individual borrowers. They also control for the number of banks as a measure of competition, which of course interacts with the concentration of the credit in a bank. They interpret their results in the sense that having closer relationships leads to lower rates, but that there is a holdup problem if a firm operates exclusively with one bank. A little bit of competition among banks reinforces the reduction in the firm's interest rate, while increasing the number of banks still more leads to pay higher interest rates. We propose to look at a measure of the cost of bank credit faced by a firm at the margin. We recur to the most expensive type of loan, overdrafts. We pick the highest observed interest rate on overdrafts paid by a firm in the financial system. This account should be the last one used by a firm, which would attempt to exhaust cheaper sources of credit first.

\section{Dataset}

A database was assembled, drawing information mainly from the Central de Deudores del Sistema Financiero (Center of Debtors of the Financial System) of the BCRA. As mentioned in the Introduction, we refer to all financial institutions as banks. The information on firms comprises incorporated firms that are "large debtors" or "principal debtors" of the financial system, which does not necessarily mean that they are large firms.

We put together a cross-section of interest rates and debt of firms with each individual bank for October 2000. This Section describes the main characteristics of this dataset. Previous researchers working with Central de Deudores, such as Berger, Klapper and Udell (2000), did not use the information on interest rates and on the balance sheets of firms because they considered the information was too unreliable, if not altogether useless. To overcome the drawbacks in the underlying information, a lot of preparatory groundwork was undertaken between December 2000 and May 2001, before running the econometric estimates.

\subsection{Assets of firms}


We were able to collect balance sheet information on 17,809 firms, of which 17,394 firms reported positive assets. However, not all the information was equally reliable. We followed two alternative approaches to tackle with the noise in the information. We first used filters to try to eliminate problematic observations. We then came up with an alternative validation process that distinguished different degrees of reliability of the information (cf. Appendix A).

In our figures of the domestic financial system in October 2000, only 16,095 of the 17,394 firms with positive assets show up, in part because the balance sheet information is mostly from 1997, 1998 and 1999. Of these 16,095 firms, 15,796 were active clients in October 2000, while the remaining firms only had write-offs. These 15,796 firms form what we call the complete sample. We also work with three different sub-samples of information that we regard as more reliable. Table 1 shows the assets of the firms in the complete sample, classified according to economic sector (note that 1 peso $=1$ dollar).

Table 1

\begin{tabular}{|c|c|c|c|c|c|}
\hline \multicolumn{6}{|c|}{$\begin{array}{l}\text { Assets of Firms in Complete Sample* } \\
\text { - in thousands of pesos - }\end{array}$} \\
\hline Sector & Cases & Minimum & Mean & Median & Maximum \\
\hline Unclas sified & 1,776 & 0.1 & 6,108 & 1,574 & 780,710 \\
\hline Agriculture, fishing or livestock & 3,076 & 0.1 & 15,106 & 2,130 & $24,400,000$ \\
\hline Mining & 111 & 0.1 & 96,351 & 4,411 & $4,363,000$ \\
\hline Industry & 3,548 & 0.1 & 68,018 & 3,409 & $126,000,000$ \\
\hline Electricity, water or gas & 125 & 11.9 & 369,145 & 63,253 & $9,719,920$ \\
\hline Construction & 1,052 & 0.1 & 23,406 & 2,519 & $5,915,785$ \\
\hline Wholesale or retail dis tribution & 2,947 & 0.1 & $19,400,000$ & 2,039 & $57,000,000,000$ \\
\hline Services & 3,161 & 0.1 & 207,216 & 2,820 & $426,000,000$ \\
\hline
\end{tabular}

* 15,796 firms.

Source: BCRA

Table 2 shows the assets of firms in the most reduced sample. This sub-sample satisfies a journalistic requirement, i.e. that two or more different sources agree on the original information (validation criteria $1 / 2 / 3 / 5 / 7$ ).

Table 2

\begin{tabular}{|c|c|c|c|c|c|}
\hline \multicolumn{6}{|c|}{$\begin{array}{l}\text { Assets of Firms in Reduced Sample** } \\
\text { - in thousands of pesos - }\end{array}$} \\
\hline Sector & Cases & Minimum & Mean & Median & Maximum \\
\hline Unclas sified & 210 & 12 & 10,242 & 4,201 & 332,296 \\
\hline Agriculture, fishing or livestock & 528 & 1 & 11,209 & 4,333 & 482,676 \\
\hline Mining & 37 & 226.6 & 84,632 & 6,282 & $1,371,330$ \\
\hline Industry & 1,352 & 0.1 & 145,819 & 8,271 & $126,000,000$ \\
\hline Electricity, water or gas & 66 & 12 & 280,561 & 132,417 & $1,993,481$ \\
\hline Construction & 369 & 58.4 & 24,532 & 5,325 & 773,847 \\
\hline Wholesale or retail distribution & 947 & 0.1 & 16,978 & 4,314 & $1,720,693$ \\
\hline Services & 908 & 0.1 & 44,842 & 5,696 & $6,281,000$ \\
\hline
\end{tabular}

$* * 4,417$ firms that satisfy validation criteria 1/2/3/5/7.

Source: BCRA

In the most restrictive sub-sample most of the outliers of the complete sample are eliminated (one of which exceeded the size of Argentina's GDP 200 times). However, this 
reduced sample is made up by only little more than $1 / 4$ of the firms, and the median size of assets is around twice as large as in the complete sample.

An intermediate sub-sample adds to this reduced group the firms whose information has been reported at least at two different dates to the BCRA, in which case we picked the most recent date. For this intermediate sample of 5,849 firms, the relation between their liabilities in the financial system in October 2000 and the book value of their assets is shown in Table 3. Though there are still outliers, the information on assets is better than in the complete sample (not shown). This sub-sample of firms will be our preferred information set for the econometric estimations.

\section{Table 3}

\begin{tabular}{|c|c|c|c|c|c|c|c|c|c|}
\hline \multicolumn{10}{|c|}{ Relation between Assets and Bank Liabilities* } \\
\hline \multicolumn{5}{|c|}{ Bank liabilities } & \multicolumn{4}{|c|}{ Assets of firms in that range } & \multirow[b]{2}{*}{ Cases } \\
\hline Decile & $\begin{array}{c}\text { Min } \\
(\$ 1000)\end{array}$ & $\begin{array}{c}\text { Max } \\
(\$ 1000)\end{array}$ & $\begin{array}{c}\text { Mean } \\
(\$ 1000)\end{array}$ & $\begin{array}{r}\text { Median } \\
(\$ 1000)\end{array}$ & $\begin{array}{c}\text { Mean } \\
(\$ 1000)\end{array}$ & $\begin{array}{c}\text { Median } \\
(\$ 1000)\end{array}$ & $\begin{array}{c}\text { Min } \\
(\$ 1000)\end{array}$ & $\begin{array}{c}\text { Max } \\
(\$ 1000)\end{array}$ & \\
\hline 1 & 0.1 & 104.9 & 42 & 38 & 13,653 & 2,299 & 1 & 662,844 & 585 \\
\hline 2 & 104.9 & 214.9 & 166 & 170 & 3,184 & 1,617 & 1 & 102,235 & 586 \\
\hline 3 & 214.9 & 314.9 & 264 & 263 & 4,235 & 1,573 & 3 & 664,844 & 585 \\
\hline 4 & 314.9 & 455.7 & 382 & 379 & 3,781 & 2,079 & 1 & 164,811 & 586 \\
\hline 5 & 455.7 & 659.0 & 550 & 542 & 23,326 & 2,591 & 1 & $5,915,785$ & 583 \\
\hline 6 & 659.0 & 987.5 & 813 & 807 & 6,557 & 3,421 & 14 & 206,641 & 586 \\
\hline 7 & 987.5 & $1,587.1$ & 1,264 & 1,249 & 9,456 & 4,914 & 201 & 656,147 & 584 \\
\hline 8 & $1,587.1$ & $2,854.1$ & 2,124 & 2,062 & 12,757 & 7,199 & 0.1 & 254,887 & 585 \\
\hline 9 & $2,854.1$ & $6,422.0$ & 4,304 & 4,160 & 32,244 & 13,907 & 1 & $1,259,205$ & 585 \\
\hline 10 & $6,422.0$ & $294,433.2$ & 30,537 & 14,097 & 414,761 & 65,177 & 0.1 & $126,000,000$ & 584 \\
\hline
\end{tabular}
Source: BCRA.

\subsection{Bank liabilities}

The information on the liabilities of each firm with the financial system covers four items: loans, unused credit lines, shares not quoted on the stock exchange, and write-offs. Though unused credit lines are a potential liability, we will simply call the aggregate figure "bank liabilities". This information on quantities is validated by the BCRA: the total for each item, added up over all the clients of each bank, has to agree with the amount reported by the bank to the BCRA on its balance sheet. If these totals do not coincide, the information is rejected.

Table 4 shows the liabilities for our complete sample of firms (including those that only have write-offs) for October 2000. The average number of operations refers to the number of banks with which firms operate on average for each line.

\section{Table 4}

\begin{tabular}{|c|c|c|c|c|c|c|}
\hline \multicolumn{7}{|c|}{ Breakdown of Bank Liabilities } \\
\hline Item & Total $(\$ 1,000)$ & $\begin{array}{l}\text { Total/no. of } \\
\text { firms * }\end{array}$ & $\begin{array}{c}\text { Firms with } \\
\text { line }(\%)\end{array}$ & $\begin{array}{c}\text { Total/firms } \\
\text { with line }\end{array}$ & $\begin{array}{c}\text { Average no. } \\
\text { operations }\end{array}$ & $\begin{array}{c}\text { Total/ no. } \\
\text { operations }\end{array}$ \\
\hline$\overline{\text { Loans }}$ & $41,460,414$ & 2,576 & 96.2 & 2,677 & 3.1 & 850 \\
\hline Unused credit lines & $4,892,558$ & 304 & 41.9 & 726 & 1.6 & 454 \\
\hline Unquoted shares & $1,209,843$ & 75 & 1.1 & 7,117 & 2.1 & 3,467 \\
\hline Write-offs & 720,395 & 45 & 9.3 & 483 & 1.9 & 251 \\
\hline Total & $48,283,210$ & 3,000 & 100.0 & 3,000 & 3.3 & 905 \\
\hline
\end{tabular}

*16,095 firms with bank liabilities reported in October 2000.

Source: Central de Deudores, BCRA. 
According to Información de Entidades Financieras published by the BCRA, liabilities in the whole financial system in September 2000 added up to 102 billion pesos, of which 36 billion corresponded to partnerships/sole proprietorships (5,162,305 cases) and 66 billion to corporations (116,960 cases). Our complete database of 16,095 firms adds up to 48 billion pesos in October 2000. These firms represent a little under $15 \%$ of the corporations, but over $75 \%$ of the debt of incorporated firms.

Starting in October 2000, a detailed breakdown of loans is available. The loans are classified into 17 different types, as presented in Table 5.

\section{Table 5}

\begin{tabular}{|c|c|c|c|c|c|c|}
\hline \multicolumn{7}{|c|}{ Breakdown of Loans } \\
\hline Type of loan & Total $(\$ 1000)$ & $\begin{array}{l}\text { Total/no. of } \\
\text { firms }\end{array}$ & \begin{tabular}{|c|} 
Firms with line \\
$(\%)$
\end{tabular} & $\begin{array}{c}\text { Total/firms } \\
\text { with line }\end{array}$ & $\begin{array}{c}\text { Average no. } \\
\text { operations }\end{array}$ & $\begin{array}{c}\text { Total } / \text { no. } \\
\text { operations }\end{array}$ \\
\hline Overdrafts & $6,138,594$ & 381 & 65.3 & 584 & 2.3 & 259 \\
\hline Dis counted bills - guarantee A 1 & 1,310 & 0 & 0.1 & 62 & 1.0 & 62 \\
\hline Discounted bills - guarantee A2 & 0 & 0 & 0 & 0 & 0 & 0 \\
\hline Bills and promissory notes & $13,990,700$ & 869 & 58.2 & 1,494 & 2.1 & 717 \\
\hline House mortgages & 19,663 & 1 & 0.6 & 195 & 1.0 & 191 \\
\hline Other mortgages & $2,380,451$ & 148 & 25.1 & 590 & 1.1 & 519 \\
\hline Car loans & 32,772 & 2 & 4.0 & 51 & 1.0 & 50 \\
\hline Other pledges & $1,072,312$ & 67 & 24.9 & 267 & 1.3 & 203 \\
\hline Personal & 44,741 & 3 & 6.8 & 41 & 1.1 & 37 \\
\hline Credit card & 195,885 & 12 & 16.8 & 73 & 1.2 & 60 \\
\hline Interfinancial & $1,866,267$ & 116 & 0.3 & 33,326 & 3.9 & 8640 \\
\hline To guaranteed public bank & 355,638 & 22 & 0.0 & 59,273 & 1.2 & 50805 \\
\hline Other loans & $13,364,295$ & 830 & 42.7 & 1,946 & 1.4 & 1376 \\
\hline Other financial & $1,228,170$ & 76 & 35.7 & 214 & 1.3 & 168 \\
\hline Leases & 702,075 & 44 & 7.2 & 610 & 1.1 & 531 \\
\hline Miscellaneous & 43,224 & 3 & 0.4 & 745 & 1.0 & 733 \\
\hline Small personal & 746 & 0 & 0.0 & 149 & 1.0 & 149 \\
\hline
\end{tabular}

Source: Central de Deudores, BCRA

There is also a breakdown of unused credit lines into four categories. Banks have to provision unused credit lines for losses in the same manner as with actual loans. If banks include a clause that allows them to revoke the credit line at any moment, they are not obliged to inform the unused portion of a credit line to the BCRA. Hence, the unused credit lines that are reported represent unused portions of loan commitment contracts.

Table 6

\begin{tabular}{|c|c|c|c|c|c|c|}
\hline \multicolumn{7}{|c|}{ Breakdown of Unused Credit Lines } \\
\hline Type of credit line & $\begin{array}{c}\text { Total } \\
(\$ 1000)\end{array}$ & Total/no. firms & $\begin{array}{c}\text { Firms with line } \\
(\%)\end{array}$ & $\begin{array}{c}\text { Total/firms } \\
\text { with line }\end{array}$ & $\begin{array}{c}\text { Average no. } \\
\text { operations }\end{array}$ & $\begin{array}{c}\text { Total/no. } \\
\text { operations }\end{array}$ \\
\hline Overdraft facilities & 381,926 & 24 & 29.0 & 82 & 1.3 & 64 \\
\hline Eventual liabilities & $1,155,193$ & 72 & 9.9 & 726 & 1.6 & 462 \\
\hline Guarantees granted & $2,790,482$ & 173 & 15.8 & 1,094 & 1.3 & 838 \\
\hline Endorsements and external credit lines & 564,957 & 35 & 0.5 & 6,494 & 1.0 & 6,348 \\
\hline
\end{tabular}

Source: Central de Deudores, BCRA.

Information on collateral for each type of loan and unused credit lines is available. Collateral is divided into guarantees of type A (the best), type B, or type C (no collateral at all).

\subsection{Interest rates on loans}


Interest rates on each type of loan, as well as the average duration of these loans, is available since October 2000. The BCRA has not yet implemented a validation procedure similar to that applied to quantities, so interest rate figures are not very reliable. Appendix B describes how this information was processed. The validated interest rate information is presented in Table 7 (the total cases in the original database are listed in the last column).

\section{Table 7}

Table 7

\begin{tabular}{|c|c|c|c|c|c|}
\hline \multicolumn{6}{|c|}{ Interest Rates in Validated Sample } \\
\hline \multirow[b]{2}{*}{ Type of Loan } & \multicolumn{4}{|c|}{ Validated sample } & \multirow{2}{*}{$\begin{array}{c}\text { Total } \\
\text { cases** }\end{array}$} \\
\hline & Mean $(\%)$ & Median (\%) & \begin{tabular}{l|l} 
Std deviation \\
\end{tabular} & Cases* & \\
\hline Overdrafts & 2.54 & 2.04 & 1.6 & 15,529 & 23,720 \\
\hline Discounted bills - guarantee A1 & 2.22 & 2.17 & 0.4 & 20 & 21 \\
\hline Bills and promissory notes & 1.28 & 1.19 & 0.5 & 13,465 & 19,517 \\
\hline House mortgages & 1.04 & 1.02 & 0.2 & 77 & 103 \\
\hline Other mortgages & 1.14 & 1.08 & 0.6 & 2,724 & 4,589 \\
\hline Car loans & 1.41 & 1.46 & 0.3 & 509 & 660 \\
\hline Other pledges & 1.27 & 1.20 & 0.9 & 2,530 & 5,279 \\
\hline Personal & 1.82 & 1.75 & 0.7 & 530 & 1,198 \\
\hline Credit card & 2.43 & 2.59 & 0.9 & 1,727 & 3,283 \\
\hline Interfinancial & 4.97 & 0.75 & 19.9 & 132 & 216 \\
\hline To guaranteed public bank & 0.91 & 0.90 & 0.1 & 7 & 7 \\
\hline Other loans & 1.39 & 1.28 & 0.8 & 5,488 & 9,712 \\
\hline Other financial & 1.07 & 1.00 & 0.5 & 1,282 & 7,327 \\
\hline Leases & 1.25 & 1.28 & 0.3 & 481 & 1,323 \\
\hline Miscellaneous & 1.09 & 0.99 & 0.8 & 47 & 59 \\
\hline Small personal & 1.12 & 0.99 & 0.2 & 5 & 5 \\
\hline
\end{tabular}

* Restricted to rates with montly values over 0.1

**All observations, including rates $<=0.1$, as well as rates reported by banks that were excluded for misreporting figures.

Source: Central de Deudores, BCRA.

Bank overdrafts are, on average, the most expensive type of loans. We disregard information on inter-financial loans, because these rates are still badly misreported in the transformed sample, since they did not even reach $2 \%$ per month in the year 2000. Besides, this assistance does not qualify for our sample that targets non-financial firms. The only other rate that is close to overdrafts is the rate charged on credit cards.

\subsection{Marginal cost of credit}

Petersen and Rajan (1994) use the cost of the last loan to measure the price of credit. This could be interpreted as an attempt to capture the cost of loans at the margin. We explicitly try to isolate a measure of the cost of bank credit faced by a firm at the margin. To identify the marginal cost, we recur to the most expensive type of loan, overdrafts. We then pick the highest observed interest rate on overdrafts paid by a firm in the financial system. This account should be the last one used by a firm, which would attempt to exhaust cheaper sources of credit first.

Applying this definition, the marginal rate turned out to be slightly above $3 \%$ per month (with small fluctuations according to the specific sub-sample of firms used). We could have used instead the highest observed interest rate charged on any type of loan. However, in $85 \%$ of the cases of firms that use overdrafts, the highest rate is indeed the rate charged on overdrafts. As to the relevance of the interest rate on overdrafts, Table 5 shows that $65 \%$ of the firms in our dataset used overdrafts in October 2000. 
An advantage of only using overdrafts is that we have a homogeneous type of loan that reduces the influence of unobserved loan characteristics on the cost of credit. The rate charged on overdrafts can be reviewed monthly. Though overdrafts can be rolled over and do not have a specified termination date, one would expect their duration to be pretty short. Table 8 presents the data on maturity. The data has never been validated, so medians seem more reliable than averages. The median of one month for overdrafts confirms that the duration of overdrafts is low.

\section{Table 8}

\begin{tabular}{|c|c|c|c|c|c|}
\hline \multicolumn{6}{|c|}{ Maturity by Loan Type* } \\
\hline Type of loan & Average months & Median months & Min & Max & Cases \\
\hline Overdrafts & 4 & 1 & 0 & 590 & 23,720 \\
\hline Discounted bills - guarantee A1 & 11 & 1 & 0 & 119 & 21 \\
\hline Bills and promissory notes & 7 & 1 & 0 & 770 & 19,517 \\
\hline House mortgages & 131 & 93 & 0 & 833 & 103 \\
\hline Other mortgages & 42 & 10 & 0 & 963 & 4,589 \\
\hline Car loans & 20 & 16 & 0 & 237 & 660 \\
\hline Other pledges & 12 & 1 & 0 & 450 & 5,279 \\
\hline Personal & 5 & 0 & 0 & 200 & 1,198 \\
\hline Credit card & 1 & 1 & 0 & 590 & 3,283 \\
\hline Interfinancial & 2 & 1 & 0 & 64 & 216 \\
\hline To guaranteed public bank & 31 & 28 & 9 & 82 & 7 \\
\hline Other loans & 7 & 1 & 0 & 925 & 9,712 \\
\hline Other financial & 9 & 1 & 0 & 999 & 7,327 \\
\hline Leases & 12 & 1 & 0 & 139 & 1,323 \\
\hline Miscellaneous & 72 & 21 & 0 & 455 & 59 \\
\hline Small personal & 7 & 6 & 2 & 15 & 5 \\
\hline
\end{tabular}

Since overdrafts are very short-term liabilities, they are overwhelmingly denominated in pesos. As the maturity lengthens, debt tends to be denominated in dollars. This is most clearly so for the debts with longest maturity, house mortgages.

Credit card lines are similar to overdrafts in several aspects. In particular, credit cards are subject both to pre-established rates and to credit limits characteristic of loan commitment contracts. We could have bunched both types of assistance together. However, we decided against doing that because they are not completely homogeneous lines. According to Table 5, the average size of operations with credit cards is substantially smaller than that of overdrafts, and their use by firms is much less widespread.

\subsection{Access to additional credit}

We had initially thought up two possible alternatives as a measure of credit constraints: one was the percentage of overdrafts over total bank credit, the other was the percentage of authorized overdrafts effectively drawn on.

As to the first alternative, our conjecture was that overdrafts would be the last type of loan a firm would resort to in the financial system. Overdrafts are more expensive than other types of loans. Moreover, their cost at the margin resembles the trade credit paid late variable in Petersen and Rajan (1994), that was charged a rate of $3 \%$ per month. If trade credit paid late could indicate that the firm faced credit constraints, we thought that a high percentage of overdrafts over total bank loans could indicate that very same thing. However, we ran into a snag, as Table 9 shows. The first column presents the median of a firm's credit situation in all 
banks. The credit situation for firms goes from 1 (the best credit standing) to 5 (the worst credit standing), while 6 is a technical category for delinquent loans with failed banks (cf. Appendix C).

Table 9

\begin{tabular}{|l|r|r|r|}
\hline \multicolumn{3}{|c|}{ Overdrafts Drawn by Credit Situation* } \\
\hline $\begin{array}{l}\text { Median of } \\
\text { credit } \\
\text { situation }\end{array}$ & Total cases & $\begin{array}{c}\text { Firms using } \\
\text { overdrafts } \\
(\%)\end{array}$ & $\begin{array}{c}\text { Overdrafts/ } \\
\text { bank loans** } \\
(\%)\end{array}$ \\
\hline 1 & 11,788 & 71.5 & 31.7 \\
1.5 & 306 & 67.6 & 21.5 \\
2 & 581 & 51.6 & 28.1 \\
2.5 & 214 & 58.9 & 24.8 \\
3 & 497 & 46.3 & 29.5 \\
3.5 & 149 & 57.0 & 25.3 \\
4 & 909 & 63.5 & 33.0 \\
4.5 & 220 & 48.6 & 37.0 \\
5 & 1,352 & 31.4 & 33.0 \\
5.5 & 32 & 28.1 & 23.5 \\
6 & 47
\end{tabular}
*This refers to complete database of 16,095 firms.
**This refers only to firms actually using overdrafts.
Source: Central de Deudores, BCRA.

Though the percentage of credit drawn through overdrafts is roughly constant across categories, the percentage of firms that actually use overdrafts tends to fall as the credit situation deteriorates. This seems to indicate that firms are cut off from overdrafts when they run into financial trouble. Unlike trade credit, whose supply might be thought of as pretty elastic, overdrafts are part of loan commitment contracts that are subject to a prior approval process. This illustrates why the use of overdrafts is an ambiguous indicator of credit rationing. Even if it is the most expensive source of credit in the financial system, the firms in worst shape have less access to it. In this sense, overdrafts have problems similar to leverage indicators discussed in Section 4.

The second alternative incorporated the feature that overdrafts are a line of credit contract subject to pre-defined quotas. Our conjecture was that the amount of unused overdrafts could provide valuable information to identify firms that were not credit constrained. Firms in good condition would tend to use overdrafts little, while firms in bad shape would tend to exhaust their available credit. Since overdrafts have a limit, and could be expected to be the last source of credit that a firm would resort to, once that limit is hit one would expect the firm to be credit constrained in the financial system.

However, we realized that, at core, Petersen and Rajan (1994) used trade credit discounts taken as a shadow indicator of credit availability in banks in general. From the start, we had such a measure of credit availability in our hands. Though we had initially thought in terms of the unused portion of authorized overdrafts, banks provide detailed information on all unused credit lines to the central bank that are part of loan commitment contracts. This perspective also ties in with the ideas in Melnik and Plaut (1986) on credit constraints having to do with the ex-post usage of credit beyond the amounts agreed on beforehand in loan commitment contracts. 
The BCRA requires banks to provision unused credit lines for credit risk, unless the credit line is revocable at any time. This means that what the figures of unused credit lines basically reflect are loans backed by loan commitment contracts that have been granted but not drawn. The following table shows the behavior of unused overdrafts in columns three and four, while columns five and six refer to total unused credit lines, that includes unused overdrafts.

Table 10

\begin{tabular}{|c|c|c|c|c|c|}
\hline \multicolumn{6}{|c|}{ Unused Credit Lines by Credit Situation } \\
\hline \multirow{2}{*}{$\begin{array}{l}\text { Median of } \\
\text { credit } \\
\text { situation }\end{array}$} & \multirow[t]{2}{*}{ Total cases } & \multicolumn{2}{|c|}{\begin{tabular}{|l|} 
Unused overdrafts \\
\end{tabular}} & \multicolumn{2}{|c|}{ Unused credit lines } \\
\hline & & $\%$ firms & $\begin{array}{c}\text { as } \% \text { of } \\
\text { liabilities* }\end{array}$ & $\%$ firms & $\begin{array}{c}\text { as } \% \text { of } \\
\text { liabilities } * *\end{array}$ \\
\hline 1 & 11,788 & 37.2 & 10.8 & 52.6 & 21.3 \\
\hline 1.5 & 306 & 23.5 & 6.2 & 33.0 & 11.2 \\
\hline 2 & 581 & 15.8 & 7.1 & 22.2 & 9.8 \\
\hline 2.5 & 214 & 9.3 & 11.8 & 16.4 & 13.1 \\
\hline 3 & 497 & 9.7 & 8.2 & 18.1 & 15.3 \\
\hline 3.5 & 149 & 6.7 & 14.7 & 10.7 & 10.3 \\
\hline 4 & 909 & 2.9 & 13.2 & 10.1 & 8.3 \\
\hline 4.5 & 220 & 1.8 & 17.3 & 7.3 & 11.4 \\
\hline 5 & 1,352 & 0.7 & 10.9 & 4.0 & 9.3 \\
\hline 5.5 & 32 & 0.0 & 0.2 & 6.3 & 0.2 \\
\hline 6 & 47 & 4.3 & 24.4 & 6.4 & 25.3 \\
\hline
\end{tabular}

For example, column five shows that $53 \%$ of firms with a median credit standing of 1 have unused credit lines, while the last column shows that this represents $21 \%$ of their bank liabilities. Only a large number of firms with the best credit situation have unused credit lines at hand, and these represent a larger share of their bank liabilities. Unused overdrafts follow approximately the same pattern, but they are less representative of available sources of funds in banks. For that reason, our final measure of credit availability was unused credit lines as a percentage of liabilities with the financial system.

\subsection{Bank relationships}

Argentina has a little developed capital market. Few firms are quoted on the stock exchange, there is a negligible domestic corporate bond market, and most firms basically have to rely on bank debt. As mentioned before, Argentina resembles what Mayer (1994) calls a banking economy, with a small proportion of quoted companies, a high concentration of ownership, and long-term relations between banks and industry, in distinction to market economies where the opposite holds. This fact makes the impact of banking relationships particularly relevant.

More generally, banking relationships are important for small and medium small and medium enterprises (SMEs) in all countries, because SMEs are typically the firms that resort the most to bank credit. Given the limited public information that they provide, SMEs have aptly been described as informationally opaque firms (Berger, Klapper, and Udell, 2000). We do not have access to the private information generated in relationships, but there are several variables that have been taken in the literature as signals of close or weak relationships. 
We use proxies to represent bank relationships. Table 11 shows the behavior of three measures of relationship as the size of financial liabilities increases. These measures of relationships refer to the number of banks a firm operates with, the extent of the business it conducts with each bank, and the importance that the main bank has in covering its financial needs.

Table 11

\begin{tabular}{|c|c|c|c|c|c|c|c|c|c|c|c|}
\hline \multicolumn{12}{|c|}{ Bank Relationships by Size of Liabilities } \\
\hline \multirow[b]{2}{*}{ Deciles } & \multicolumn{5}{|c|}{ Liabilities } & \multicolumn{2}{|c|}{ No. banks } & \multicolumn{2}{|c|}{ No. credit lines* } & \multicolumn{2}{|c|}{ Liabilities main bank* } \\
\hline & Cases & $\begin{array}{c}\text { Min } \\
(\$ 1000)\end{array}$ & $\begin{array}{c}\text { Max } \\
(\$ 1000)\end{array}$ & $\begin{array}{l}\text { Mean } \\
(\$ 1000)\end{array}$ & $\begin{array}{r}\text { Median } \\
(\$ 1000)\end{array}$ & Average & Median & Average & Median & $\begin{array}{c}\text { Average } \\
(\%)\end{array}$ & $\begin{array}{c}\text { Median } \\
(\%)\end{array}$ \\
\hline 1 & 1,610 & 0.1 & 41 & 13 & 9 & 1.5 & 1 & 1.2 & 1 & 92 & 100 \\
\hline 2 & 1,611 & 41 & 127 & 84 & 83 & 2.1 & 2 & 1.5 & 1 & 83 & 94 \\
\hline 3 & 1,610 & 127 & 205 & 168 & 168 & 2.3 & 2 & 1.6 & 2 & 81 & 89 \\
\hline 4 & 1,609 & 205 & 272 & 237 & 235 & 2.4 & 2 & 1.6 & 2 & 81 & 90 \\
\hline 5 & 1,609 & 272 & 363 & 314 & 312 & 2.7 & 2 & 1.6 & 2 & 78 & 81 \\
\hline 6 & 1,608 & 363 & 502 & 427 & 425 & 3.0 & 3 & 1.7 & 2 & 74 & 74 \\
\hline 7 & 1,610 & 502 & 757 & 613 & 606 & 3.3 & 3 & 1.7 & 2 & 71 & 71 \\
\hline 8 & 1,609 & 757 & 1,342 & 1,007 & 982 & 4.0 & 4 & 1.8 & 2 & 67 & 64 \\
\hline 9 & 1,610 & 1,342 & 3,413 & 2,127 & 2,001 & 4.8 & 4 & 1.8 & 1.8 & 64 & 61 \\
\hline 10 & 1,609 & 3,413 & $1,702,432$ & 25,017 & 7,856 & 7.0 & 6 & 1.7 & 1.7 & 56 & 51 \\
\hline
\end{tabular}

The average number of financial institutions (no. banks) is inversely related to the strength of a bank relationship. The number of banks rises with the size of liabilities, so larger firms rely less on any given financial institution (they also rely as a rule less on bank credit to finance their needs).

The average number of types of loans, unused credit lines and unquoted shares (no. credit lines) is directly related to the strength of a relationship. The number of operations with each financial institution shows no marked upward trend with size. Note that there are up to 17 types of loans, 4 types of unused credit lines, and unquoted shares count as 1 , so this variable can reach a maximum value of 22 .

The concentration of operations with the largest creditor institution, measured by the ratio of the liabilities in the main bank to liabilities in the financial system (where liabilities exclude write-offs in both cases), is directly related to the strength of the relationship with the main bank. The concentration decreases with the size of liabilities. However, even in the largest decile the median firm conducts $50 \%$ of its business with a single institution.

Note that only in the last three deciles of Table 11 are there firms with liabilities in the domestic financial system above a million pesos. If one takes as a working definition of SMEs those firms that receive less than 2.5 millions in loans from the financial system (Burdisso, D'Amato, Escudé and McCandless, 2001), over 85\% of the firms in our complete sample are SMEs. On the other hand, in the more restrictive set of firms that satisfies validation criteria $1 / 2 / 3 / 5 / 7 / 13$, Table 3 shows that over $75 \%$ are SMEs applying this same criterion of bank debt.

\section{Econometric evidence}

Our goal here is to see what can be learned on the high cost and the limited access of firms to credit in Argentina from the cross-sectional variation among firms. We try to measure the cost and the availability of bank credit at the margin. Our methodology is inspired by Petersen and Rajan (1994). Besides some differences in the right-hand variables that in particular extend the 
study to see the impact of credit history, we use different left-hand variables, which can be related to the ideas of loan commitment contracts in Melnik and Plaut (1986).

The cost of credit is captured by the marginal interest rate that a firm has to pay on overdrafts. As to the access to credit, we start by running some regressions based on leverage similar to those commonly used in the literature. However, high leverage is inherently ambiguous because they may indicate either a firm with high credit availability or a firm in financial distress. We then propose an alternative approach to detect credit constrained firms based on the proportion of outstanding credit lines.

In each case, we first run regressions for different subsets of information, to see if more restrictive validation criteria lead to more precise estimates. Naturally, a more restrictive validation criterion leaves fewer observations, hopefully of better quality for the problem analyzed. So there is an implicit trade-off when restricting the sample where degrees of freedom are sacrificed to obtain more relevant observations.

We are interested in evaluating how information affects credit conditions. If banks can screen between good and bad credits more easily, this should reduce the problem of lemons, improving the access to credit of good firms. Do close relationships matter? It seems they do, reducing the cost of credit and increasing the access to credit. We interpret that firms with closer ties to financial institutions not only share a lot of information with banks, they also show they are good credits. Otherwise, if the firm were bad, the bank would want to turn away from the relationship once it got to know the firm better.

Does credit history matter? It seems to matter, but whereas the negative effect on the access to credit seems to increase monotonically as the credit history deteriorates, the effect on interest rates is more of a step function. This makes sense from the perspective of credit rationing, since raising the interest rates to firms in very bad shape only increases the probability of default.

Public information also seems to matter, since the credit history in other financial institutions impacts the access to credit of a bank's client. We also control for characteristics of a firm from financial statements, as well as for characteristics of banks and loans, and, when possible, for the industrial sector to which the firm belongs.

\subsection{Overdraft rate at marginal bank}

In the interest rate regression, our dependent variable is the interest rate paid by firms on their overdraft account. We consider that this account is the informative account. In case a firm uses more than one overdraft account, the paper uses the overdraft account that pays the highest interest rate. Using this definition, the marginal overdraft interest rate is on average slightly above $3 \%$ per month.

The fact that a firm can switch overnight from one account to another, or from one bank to another, canceling its outstanding overdrafts, allows to interpret the most expensive overdraft account used as the marginal account. As discussed in Section 3, the interest rate on overdrafts is an interest rate relevant for most of the firms with relationship with the financial sector, and it is used more often than any other single line. In those firms actually using overdrafts, it is almost always the highest recorded rate.

From an econometric perspective, the advantage of concentrating the analysis on the rate of a specific credit line is that we do not have to model the influence of line-specific factors that 
affect the underlying rate. Those controls would be necessary if the analysis were to be made on the highest rate charged on any line. In addition, the characteristic that this account is priced monthly facilitates the estimation procedure, because there is no need to introduce extra variables to measure the underlying cost. The constant of the regression should capture it. The paper estimates the following regression function:

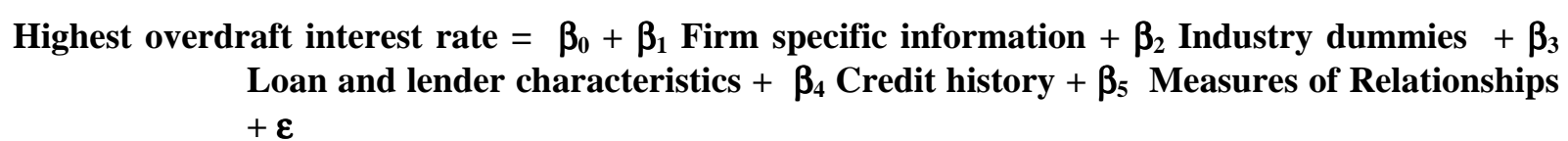

The equation introduces controls for firm specific information, industry dummies, and loan and lender characteristics. We follow Petersen and Rajan (1994) in using relationship characteristics to capture the influence of private information. Variables on credit history, not used by Petersen and Rajan (1994), are also introduced in the regressions. Greene (1992) emphasizes the role of credit history for interest rates and access to credit. Parameters are estimated by ordinary least squares using the Eicker-White heteroskedasticity consistent estimator for standard errors.

The columns of Table 12 display four different sets of firms. Regression one corresponds to the complete sample, while regression two applies a filter to eliminate problematic observations (roa $=0$, and cases where either assets or liabilities or net worth are between 0 and 1 thousand pesos). Regression three corresponds to registers where at least two sources agree on the information (validation criteria 1/2/3/5/7). Regression four also includes firms whose balance sheet information has been regularly updated by a bank (validation criterion 13). This information, though it cannot be crossed with other reports, seems to behave pretty much like the information that can be checked. Given the large heterogeneity of the sample considered, the possible presence of outliers that can seriously affect least squares estimates cannot be discarded in advance. We also estimated all models using robust methods. We used Huber's biweight function based on Cook's distance (see Wilcox, 1997, for details). The robust estimates (not shown) are fairly similar to those obtained by OLS, so outliers do not affect the estimation significantly.

Table 12 


\begin{tabular}{|c|c|c|c|c|}
\hline \multicolumn{5}{|c|}{ Interest Rate Regressions: Different Sub-samples } \\
\hline Explanatory variables & $\begin{array}{c}\text { Complete } \\
\text { sample }\end{array}$ & $\begin{array}{c}\text { Complete } \\
\text { sample }^{+}\end{array}$ & $\begin{array}{l}\text { Reduced } \\
\text { sample }^{++}\end{array}$ & $\begin{array}{c}\text { Reduced } \\
\text { sample }^{+++}\end{array}$ \\
\hline \multirow[t]{2}{*}{ roa } & 0.000 & 0.000 & 0.076 & 0.075 \\
\hline & $(-1.12)$ & $(-1.12)$ & $(1.06)$ & (1.07) \\
\hline \multirow[t]{2}{*}{ lnassets } & -0.100 & -0.125 & -0.150 & -0.129 \\
\hline & $(-9.18) * * *$ & $(-8.72) * * *$ & $(-6.85) * * *$ & $(-6.98) * * *$ \\
\hline \multirow[t]{2}{*}{ Insales/assets } & -0.246 & -0.245 & -0.189 & -0.180 \\
\hline & $(-6.39) * * *$ & $(-5.32) * * *$ & $(-2.36) * *$ & $(-2.68) * * *$ \\
\hline \multirow[t]{2}{*}{ lndebt/assets } & 0.011 & 0.154 & 0.624 & 0.452 \\
\hline & $(0.12)$ & $(1.41)$ & $(2.83) * * *$ & $(2.45) * *$ \\
\hline \multirow[t]{2}{*}{ sector 0} & 0.215 & 0.110 & -0.160 & 0.020 \\
\hline & $(3.2) * * *$ & (1.4) & $(-1.15)$ & $(0.19)$ \\
\hline \multirow[t]{2}{*}{ sector 1} & 0.129 & 0.130 & -0.004 & 0.110 \\
\hline & $(2.24) * *$ & $(2.03) * *$ & $(-0.04)$ & (1.22) \\
\hline \multirow[t]{2}{*}{ sector 3} & -0.033 & -0.075 & -0.434 & -0.237 \\
\hline & $(-0.16)$ & $(-0.35)$ & $(-1.31)$ & $(-0.87)$ \\
\hline \multirow[t]{2}{*}{ sector 5} & -0.059 & 0.010 & -0.306 & -0.244 \\
\hline & $(-0.29)$ & $(0.05)$ & $(-1.12)$ & $(-0.96)$ \\
\hline \multirow[t]{2}{*}{ sector 6} & 0.272 & 0.223 & 0.163 & 0.220 \\
\hline & $(3.78) * * *$ & $(2.84) * * *$ & (1.38) & $(2.09) * *$ \\
\hline \multirow{2}{*}{ sector 7} & 0.110 & 0.066 & -0.086 & -0.003 \\
\hline & $(2.16) * *$ & (1.19) & $(-1.05)$ & $(-0.04)$ \\
\hline \multirow[t]{2}{*}{ sector 8} & 0.302 & 0.266 & 0.158 & 0.198 \\
\hline & $(5.65) * * *$ & $(4.55) * * *$ & $(1.76) *$ & $(2.54) * *$ \\
\hline \multirow[t]{2}{*}{ situation 2} & 0.652 & 0.539 & 0.511 & 0.577 \\
\hline & $(6.32) * * *$ & $(4.71)^{* * *}$ & $(2.98) * * *$ & $(3.72) * * *$ \\
\hline \multirow[t]{2}{*}{ situation 3} & 0.252 & 0.258 & 0.002 & 0.084 \\
\hline & $(2.62) * * *$ & $(2.44) * *$ & $(0.014)$ & $(0.56)$ \\
\hline \multirow[t]{2}{*}{ situation 4} & 0.422 & 0.501 & 0.538 & 0.475 \\
\hline & $(5.87) * * *$ & $(6.23) * * *$ & $(4.66) * * *$ & $(4.45) * * *$ \\
\hline situation 5 & 0.228 & 0.121 & 0.170 & 0.205 \\
\hline & $(2.22) * *$ & $(0.97)$ & $(0.95)$ & (1.23) \\
\hline situation 6 & 0.811 & 0.994 & 0.698 & 0.767 \\
\hline & $(2.55) * *$ & $(2.41) * *$ & $(1.69) *$ & $(1.9) *$ \\
\hline Inbounced/liabilities & 0.048 & 0.049 & 0.072 & 0.066 \\
\hline & $(5.42) * * *$ & $(4.88) * * *$ & $(4.62) * * *$ & $(4.67) * * *$ \\
\hline unwarranted/overdrafts & 0.896 & 0.903 & 0.893 & 0.963 \\
\hline & $(10.19) * * *$ & $(9.09) * * *$ & $(5.49) * * *$ & $(6.9) * * *$ \\
\hline foreign bank $=1$ & 0.198 & 0.153 & 0.165 & 0.146 \\
\hline & $(5.09) * * *$ & $(3.54) * * *$ & $(2.51) * *$ & $(2.55) * *$ \\
\hline public bank $=1$ & 0.110 & 0.213 & 0.295 & 0.261 \\
\hline & $(1.27)$ & $(1.99) *$ & $(1.7)^{*}$ & (1.63) \\
\hline wholesale bank $=1$ & -1.000 & -1.005 & -0.989 & -1.011 \\
\hline & $(-11.33) * * *$ & $(-10.62) * * *$ & $(-7.99) * * *$ & $(-8.9) * * *$ \\
\hline bank's market share & -8.779 & -9.118 & -9.484 & -8.724 \\
\hline & $(-15.54) * * *$ & $(-14.56) * * *$ & $(-9.84) * * *$ & $(-10.36) * * *$ \\
\hline liabilities bank/system & -0.690 & -0.647 & -0.653 & -0.646 \\
\hline & $(-11.21) * * *$ & $(-9.27) * * *$ & $(-5.39) * * *$ & $(-6.45) * * *$ \\
\hline no. banks & 0.069 & 0.084 & 0.092 & 0.090 \\
\hline & $(9.06) * * *$ & $(10.11) * * *$ & $(8.45) * * *$ & $(8.89) * * *$ \\
\hline no. credit lines & -0.129 & -0.136 & -0.133 & -0.142 \\
\hline & $(-7.23) * * *$ & $(-6.84) * * *$ & $(-4.38) * * *$ & $(-5.37) * * *$ \\
\hline _cons & 3.525 & 3.646 & 3.617 & 3.396 \\
\hline & $(24.65) * * *$ & $(20.68) * * *$ & $(12.73) * * *$ & $(14.33) * * *$ \\
\hline Number of observations & 8548 & 7010 & 3112 & 3963 \\
\hline $\mathrm{F}$ & 63.44 & 55.34 & 25.91 & 33.52 \\
\hline Prob $>$ F & 0 & 0 & 0 & 0 \\
\hline R-squared & 0.1569 & 0.1653 & 0.1735 & 0.1755 \\
\hline Adj R-squared & 0.1544 & 0.1623 & 0.1668 & 0.1703 \\
\hline Root MSE & 1.58 & 1.5859 & 1.6279 & 1.5897 \\
\hline Estimation method & OLS & OLS & OLS & OLS \\
\hline
\end{tabular}

${ }^{+}$Excludes ro $=0$ and balance sheets with problems.

${ }^{++}$Validation criteria 1/2/3/5/7.

${ }^{+++}$Validation criteria 1/2/3/5/7/13.

Note: $\mathrm{t}$-statistics in parenthesis. 1, 2 and 3 asterisks indicate significance at $10 \%, 5 \%$ or $1 \%$. 
Though we are more confident in the samples of regressions three and four, the estimates in Table 12 are not very sensitive to the specific sample used. In the initial estimates, many coefficients in the first two regressions had signs significantly different from the last two regressions. Once more controls were put in place, the most noteworthy difference is that in the first two regressions lndebt/assets is not statistically significant, and that roa has a negative sign (though it is never statistically significant). ${ }^{2}$ Please see Appendix D for a full description of the right-hand variables.

The main results on the cost of credit (skipping the controls for industry dummies sector*) are as follows. Looking at a firm's characteristics, the cost of credit is negatively and significantly associated with the amount of assets (lnassets), and the sales/assets ratio (Insales/assets), while it is positively and significantly related with the firm's debt/assets ratio (Indebt/assets). As to credit history, the cost of credit is positively related to a worse credit situation (situation*) and to bounced checks in the marginal bank (Inbounced/liabilities). However, in the case of credit situation the coefficients are not always significant, and they do not increase with the deterioration of the credit situation. Relationship variables show that the cost of credit is negatively and significantly associated with debt concentration in the marginal bank (liabilities bank/system), and to the number of accounts in the marginal bank (no. credit lines), but it is positively and significantly related to the number of banks (no. banks). While Table 11 shows that the number of banks increases with the size of liabilities in the financial system, the regressions control for the size of firms (lnassets), so an effect of size can be ruled out. Other significant controls show that less collateral (unwarranted/overdrafts) leads to pay higher interest rates, that marginal banks that are wholesale (wholesale bank) or large (bank's market share) charge lower interest rates, and that marginal banks that are foreign (foreign bank) charge higher interest rates.

We want to comment in more detail the effects of credit history. The variable on bounced checks is measured as the ratio in the marginal bank between the amount in bounced checks from January to September 2000, and liabilities. There are five dummy variables on credit situation of each firm. Situation 1 is omitted, so it acts as the benchmark. Although not all parameters are significantly different from zero in the four estimates, all of the coefficients are positive. This indicates that firms with poor credit situation tend to pay higher interest rates. What's more, if only a dummy for credit situation 1 is included, it is negative and statistically significant (we do not show the regression for space considerations). The interest rates do not increase as the credit situation worsens to situation 4, which corresponds to firms under debt rescheduling proceedings, or situation 5, which corresponds to firms filing for bankruptcy. Since situation 6 is a technical category that represents arrears with financial institutions that went broke, it cannot be ranked as worse than either situation 4 or 5 . These results may be interpreted as an indication of credit rationing. As the risk of default increases, beyond a certain point it makes no sense to increase the interest rate further. Rather, banks will simply cut back the amount of credit, as we discuss below.

As to the relationship variables, the variable liabilities bank/system is an indication of how deep the marginal bank's involvement in the firm is. An increase in this variable means that the bank has a higher stake in the firm. This higher exposition assumed by a bank also generates the right incentive to monitor the firm carefully. On the other hand, it could possibly indicate that

\footnotetext{
${ }^{2}$ All the variables defined as $\ln \mathrm{x}$ are calculated adding 1 thousand pesos to $\mathrm{x}$, $\operatorname{so} \ln (1+\mathrm{x})$ is the actual explanatory variable. This transformation is
} due to the many zeros that appear in the regression with the complete sample. Otherwise we would lose a lot of observations. 
the firm does not have access to other banks. In this case the parameter of this variable should have a positive sign, signaling the firm's risk. According to the result of Table 12, the effect of debt concentration in the marginal bank is explained by the first hypothesis.

A second variable to control for relationships, no. credit lines, is the number of accounts the firm is using in the marginal bank. Each type of bank account generates different information. Although not all accounts are informative, we consider the total number of accounts as a proxy for informative accounts. The results from the regressions show that firms with more accounts are charged lower interest rates.

A third variable for relationships, no. banks, does not have a straightforward sign. The issues are similar to the variable liabilities bank/system. ${ }^{3}$ On the one hand, this variable could signal that a firm wants to diversify its financing sources to not be a captive client of a single bank. If this is the case, an increase in the number of banks should reduce the interest rate. On the other hand, this variable could signal that the relationship is weaker, in which case an increase in the number of banks should go hand in hand with an increase in the interest rate paid. The interest rate paid could also rise if more banks signaled that the marginal bank can not monitor as effectively the firm, or also if it signals that the main bank cut the firm's access to credit, forcing it to seek other lenders. According to the results in Table 12, firms that operate in more banks are charged higher interest rates, so it signals either weaker relationships, or moral hazard and quality problems. Taking into account the quantity effects to be discussed below, the additional effects of the variable no. banks may indeed be an indication of firms that need to resort to finance at another bank because they are cut off by their main lender.

Besides the basic regressions in Table 12, we ran alternative regressions using our preferred set of firms (validation criteria 1/2/3/5/7/13).

\section{Table 13}

\footnotetext{
${ }^{3}$ Note that the number of banks (no. banks) is not completely independent from the concentration of business in the marginal bank (liabilities bank/system). This is forcefully so when no. banks=1, which implies liabilities bank/system=1. However, the mean value of no. bank in regression four is 5.1 banks. Besides, the two variables do not have a very high positive correlation.
} 


\begin{tabular}{|c|c|c|c|c|}
\hline \multicolumn{5}{|c|}{ Interest Rate Regressions: Additional Variables } \\
\hline Explanatory variables & $\begin{array}{l}\text { Reduced } \\
\text { sample }^{+}\end{array}$ & $\begin{array}{c}\text { Reduced } \\
\text { sample }^{+}\end{array}$ & $\begin{array}{c}\text { Reduced } \\
\text { sample }^{+}\end{array}$ & $\begin{array}{c}\text { Reduced } \\
\text { sample }^{+}\end{array}$ \\
\hline roa & $\begin{array}{c}0.075 \\
(1.07)\end{array}$ & $\begin{array}{c}0.079 \\
(1.13)\end{array}$ & $\begin{array}{l}0.080 \\
(1.14)\end{array}$ & $\begin{array}{l}0.080 \\
(1.15)\end{array}$ \\
\hline lnassets & $\begin{array}{c}-0.129 \\
(-6.98) * * *\end{array}$ & $\begin{array}{c}-0.120 \\
(-6.39) * * *\end{array}$ & $\begin{array}{c}-0.120 \\
(-6.41)^{* * *}\end{array}$ & $\begin{array}{c}-0.119 \\
(-6.36)^{* * *}\end{array}$ \\
\hline Insales/assets & $\begin{array}{c}-0.180 \\
(-2.68) * * *\end{array}$ & $\begin{array}{c}-0.176 \\
(-2.64) * * *\end{array}$ & $\begin{array}{c}-0.178 \\
(-2.66)^{* * *}\end{array}$ & $\begin{array}{c}-0.173 \\
(-2.59)^{* * *}\end{array}$ \\
\hline lndebt/assets & $\begin{array}{c}0.452 \\
(2.45)^{* *}\end{array}$ & $\begin{array}{c}0.437 \\
(2.37)^{* *}\end{array}$ & $\begin{array}{c}0.441 \\
(2.39)^{* * *}\end{array}$ & $\begin{array}{c}0.445 \\
(2.41)^{* *}\end{array}$ \\
\hline sector 0 & $\begin{array}{c}0.020 \\
(0.19)\end{array}$ & $\begin{array}{c}0.033 \\
(0.32)\end{array}$ & $\begin{array}{l}0.034 \\
(0.32)\end{array}$ & $\begin{array}{l}0.027 \\
(0.26)\end{array}$ \\
\hline sector 1 & $\begin{array}{r}0.110 \\
(1.22)\end{array}$ & $\begin{array}{l}0.111 \\
(1.23)\end{array}$ & $\begin{array}{l}0.111 \\
(1.23)\end{array}$ & $\begin{array}{l}0.100 \\
(1.11)\end{array}$ \\
\hline sector 3 & $\begin{array}{c}-0.237 \\
(-0.87)\end{array}$ & $\begin{array}{c}-0.249 \\
(-0.92)\end{array}$ & $\begin{array}{l}-0.249 \\
(-0.91)\end{array}$ & $\begin{array}{l}-0.249 \\
(-0.91)\end{array}$ \\
\hline sector 5 & $\begin{array}{c}-0.244 \\
(-0.96)\end{array}$ & $\begin{array}{c}-0.234 \\
(-0.92)\end{array}$ & $\begin{array}{l}-0.234 \\
(-0.92)\end{array}$ & $\begin{array}{l}-0.237 \\
(-0.93)\end{array}$ \\
\hline sector 6 & $\begin{array}{c}0.220 \\
(2.09) * *\end{array}$ & $\begin{array}{l}0.210 \\
(2) * *\end{array}$ & $\begin{array}{l}0.211 \\
(2)^{* *}\end{array}$ & $\begin{array}{c}0.209 \\
(1.99) * *\end{array}$ \\
\hline sector 7 & $\begin{array}{c}-0.003 \\
(-0.04)\end{array}$ & $\begin{array}{c}-0.004 \\
(-0.06)\end{array}$ & $\begin{array}{l}-0.004 \\
(-0.06)\end{array}$ & $\begin{array}{l}-0.011 \\
(-0.15)\end{array}$ \\
\hline sector 8 & $\begin{array}{c}0.198 \\
(2.54) * *\end{array}$ & $\begin{array}{c}0.195 \\
(2.51) * *\end{array}$ & $\begin{array}{c}0.195 \\
(2.51)^{* *}\end{array}$ & $\begin{array}{c}0.182 \\
(2.39)^{* *}\end{array}$ \\
\hline situation 2 & $\begin{array}{c}0.577 \\
(3.72) * * *\end{array}$ & $\begin{array}{c}0.525 \\
(3.38)^{* * *}\end{array}$ & $\begin{array}{c}0.504 \\
(3.16)^{* * * *}\end{array}$ & $\begin{array}{c}0.505 \\
(3.17)^{* * * *}\end{array}$ \\
\hline situation 3 & $\begin{array}{c}0.084 \\
(0.56)\end{array}$ & $\begin{array}{c}0.014 \\
(0.09)\end{array}$ & $\begin{array}{l}0.000 \\
(0.00)\end{array}$ & $\begin{array}{l}0.004 \\
(0.02)\end{array}$ \\
\hline situation 4 & $\begin{array}{c}0.475 \\
(4.45) * * *\end{array}$ & $\begin{array}{c}0.379 \\
(3.46) * * *\end{array}$ & $\begin{array}{c}0.376 \\
(3.43) * * *\end{array}$ & $\begin{array}{c}0.394 \\
(3.59)^{* * * *}\end{array}$ \\
\hline situation 5 & $\begin{array}{c}0.205 \\
(1.23)\end{array}$ & $\begin{array}{c}0.178 \\
(1.07)\end{array}$ & $\begin{array}{l}0.160 \\
(0.95)\end{array}$ & $\begin{array}{l}0.174 \\
(1.03)\end{array}$ \\
\hline situation 6 & $\begin{array}{c}0.767 \\
(1.9)^{*}\end{array}$ & $\begin{array}{c}0.695 \\
(1.73) *\end{array}$ & $\begin{array}{l}0.645 \\
(1.57)\end{array}$ & $\begin{array}{l}0.630 \\
(1.53)\end{array}$ \\
\hline lnbounced/liabilities & $\begin{array}{c}0.066 \\
(4.67) * * *\end{array}$ & $\begin{array}{c}0.049 \\
(3.31)^{* * * *}\end{array}$ & $\begin{array}{c}0.049 \\
(3.34)^{* * * *}\end{array}$ & $\begin{array}{c}0.048 \\
(3.24)^{* * *}\end{array}$ \\
\hline unwarranted/overdrafts & $\begin{array}{c}0.963 \\
(6.9) * * *\end{array}$ & $\begin{array}{c}0.971 \\
(6.96) * * *\end{array}$ & $\begin{array}{c}0.973 \\
(6.98)^{* * *}\end{array}$ & $\begin{array}{c}0.973 \\
(6.98)^{* * *}\end{array}$ \\
\hline foreign bank $=1$ & $\begin{array}{c}0.146 \\
(2.55) * *\end{array}$ & $\begin{array}{c}0.157 \\
(2.75) * * *\end{array}$ & $\begin{array}{c}0.157 \\
(2.74)^{* * *}\end{array}$ & $\begin{array}{c}0.162 \\
(2.83)^{* * *}\end{array}$ \\
\hline public bank $=1$ & $\begin{array}{c}0.261 \\
(1.63)\end{array}$ & $\begin{array}{c}0.262 \\
(1.64)\end{array}$ & $\begin{array}{c}0.263 \\
(1.65)^{*}\end{array}$ & $\begin{array}{l}0.247 \\
(1.54)\end{array}$ \\
\hline wholesale bank $=1$ & $\begin{array}{c}-1.011 \\
(-8.9) * * *\end{array}$ & $\begin{array}{c}-1.004 \\
(-8.85) * * *\end{array}$ & $\begin{array}{c}-1.005 \\
(-8.86)^{* * *}\end{array}$ & $\begin{array}{c}-1.007 \\
(-8.88)^{* * *}\end{array}$ \\
\hline bank's market share & $\begin{array}{c}-8.724 \\
(-10.36) * * *\end{array}$ & $\begin{array}{c}-8.749 \\
(-10.4) * * *\end{array}$ & $\begin{array}{c}-8.771 \\
(-10.42)^{* * *}\end{array}$ & $\begin{array}{c}-8.864 \\
(-10.52) * * *\end{array}$ \\
\hline $\begin{array}{l}\text { liabilities bank/system } \\
\text { no. banks }\end{array}$ & $\begin{array}{c}-0.646 \\
(-6.45) * * * \\
0.090 \\
(8.9) * * *\end{array}$ & $\begin{array}{c}-0.624 \\
(-6.23) * * * \\
0.086 \\
(8.46) * * *\end{array}$ & $\begin{array}{c}-0.623 \\
(-6.22)^{* * *} \\
0.086 \\
(8.47)^{* * *}\end{array}$ & $\begin{array}{c}-0.720 \\
(-6.63)^{* * *} \\
0.033 \\
(1.32)\end{array}$ \\
\hline no. credit lines & $\begin{array}{c}-0.142 \\
(-5.37) * * *\end{array}$ & $\begin{array}{c}-0.139 \\
(-5.27) * * *\end{array}$ & $\begin{array}{c}-0.140 \\
(-5.28)^{* * *}\end{array}$ & $\begin{array}{c}-0.133 \\
(-5)^{* * *}\end{array}$ \\
\hline _cons & $\begin{array}{c}3.396 \\
(14.33) * * *\end{array}$ & $\begin{array}{c}3.282 \\
(13.76) * * *\end{array}$ & $\begin{array}{c}3.285 \\
(13.76)^{* * *}\end{array}$ & $\begin{array}{c}3.444 \\
(13.87)^{* * *}\end{array}$ \\
\hline bounced other bank $=1$ & - & $\begin{array}{c}0.295 \\
(3.79)^{* * *}\end{array}$ & $\begin{array}{c}0.297 \\
(3.81)^{* * *}\end{array}$ & $\begin{array}{c}0.308 \\
(3.95)^{* * * *}\end{array}$ \\
\hline system situation $(-1,0,1)$ & - & - & $\begin{array}{l}-0.049 \\
(-0.58)\end{array}$ & $\begin{array}{l}-0.049 \\
(-0.58)\end{array}$ \\
\hline no. banks square & - & - & $\begin{array}{l}- \\
-\end{array}$ & $\begin{array}{c}0.003 \\
(2.31)^{* * *}\end{array}$ \\
\hline Number of obs. & 3963 & 3963 & 3963 & 3963 \\
\hline $\mathrm{F}$ & 33.52 & 32.89 & 31.68 & 30.77 \\
\hline Prob $>$ F & 0 & 0 & 0 & 0 \\
\hline R-squared & 0.1755 & 0.1785 & 0.1786 & 0.1797 \\
\hline Adj R-squared & 0.1703 & 0.1731 & 0.1729 & 0.1738 \\
\hline Root MSE & 1.5897 & 1.5871 & 1.5872 & 1.5863 \\
\hline Estimation method & OLS & OLS & OLS & OLS \\
\hline
\end{tabular}

${ }^{+}$Validation Criteria 1/2/3/5/7/13

Note: $t$-statistics in parenthesis. 1,2 and 3 asterisks indicate significance at $10 \%, 5 \%$ or $1 \%$. 
The only significant change in Table 13 is that when a quadratic term for number of banks is introduced (no. banks square), the linear term, though still positive, loses its statistical significance. The quadratic term is positive and significant, so the effect of number of banks is convex, leading to increasingly higher marginal rates. If anything, this confirms the interpretation of number of banks as a distress signal, where a firm that is more needy of funds faces steeply increasing financing costs at the margin.

A dummy variable for bounced checks in other banks (bounced other bank) turns out to be significant, though this was not public information released at the time by the BCRA. It only became public in mid-2001. Bounced checks might perhaps have been shared among banks, or revealed thanks to clearing houses. There was a dummy for differences between the rating of the firm in the marginal bank and in the median of the financial system, system situation, which took a value of 1 if the median situation in the system was worse, and -1 if it was better. This variable turned out to not be statistically significant.

\subsection{Leverage}

The measurement of access to credit is not an easy task. Leverage is commonly used in the applied literature. We experimented with the ratio of several different measures of debt to assets, from broader ones to more restricted ones. The dependent variable was one of four measures of a firm's debt ratio:

- Indebt/assets: natural log of [1+(debt/assets) ]

- Inliabilities/a.: log of [1+(bank liabilities/assets) ]

- Inloans/a.: $\log$ of [1+(bank loans/assets) ]

- lnoverdraft/a.: log of [1+(bank overdrafts/assets) ]

Except for the first variable, where liabilities and assets are taken from balance sheets at the same point in time, in the other case there is some noise. We divide a figure of debt with the financial system in October 2000 by the assets reported in the last available balance sheet statement. The balance sheet information is mostly from 1998 and 1999. But since the economy on average has not grown since 1998 due to a prolonged slump (followed by a strong downward slide in 2001), it is not clear that there is any bias. Table 14 shows the estimates with one of the sub-samples. The results with the complete sample of firms are similar.

\section{Table 14}




\begin{tabular}{|c|c|c|c|c|}
\hline \multicolumn{5}{|c|}{ Debt-Ratio Regressions $^{+}$} \\
\hline Explanatory variables & lndebt/assets & Inliabilities/a. & lnloans/a. & lnoverdrafts/a. \\
\hline roa & $\begin{array}{c}-0.009 \\
(-1.52)\end{array}$ & $\begin{array}{c}0.055 \\
(3.51) * * *\end{array}$ & $\begin{array}{c}0.055 \\
(3.44) * * *\end{array}$ & $\begin{array}{c}0.003 \\
(0.17)\end{array}$ \\
\hline lnassets & $\begin{array}{c}0.009 \\
(6.81) * * *\end{array}$ & $\begin{array}{c}-0.133 \\
(-37.4) * * *\end{array}$ & $\begin{array}{c}-0.135 \\
(-36.44) * * *\end{array}$ & $\begin{array}{c}-0.069 \\
(-19.02) * * *\end{array}$ \\
\hline Insales/assets & $\begin{array}{c}0.112 \\
(23.14)^{* * *}\end{array}$ & $\begin{array}{c}-0.142 \\
(-11.42) * * *\end{array}$ & $\begin{array}{c}-0.124 \\
(-9.68) * * *\end{array}$ & $\begin{array}{c}-0.030 \\
(-2.47) * *\end{array}$ \\
\hline sector 0 & $\begin{array}{c}-0.002 \\
(-0.26)\end{array}$ & $\begin{array}{c}-0.032 \\
(-1.51)\end{array}$ & $\begin{array}{c}-0.035 \\
(-1.66) *\end{array}$ & $\begin{array}{c}-0.010 \\
(-0.51)\end{array}$ \\
\hline sector 1 & $\begin{array}{c}-0.016 \\
(-2.31)^{* *}\end{array}$ & $\begin{array}{c}-0.040 \\
(-2.27) * *\end{array}$ & $\begin{array}{c}-0.034 \\
(-1.84)^{*}\end{array}$ & $\begin{array}{c}-0.008 \\
(-0.43)\end{array}$ \\
\hline sector 3 & $\begin{array}{c}-0.043 \\
(-1.98) * *\end{array}$ & $\begin{array}{c}-0.022 \\
(-0.41)\end{array}$ & $\begin{array}{c}-0.040 \\
(-0.69)\end{array}$ & $\begin{array}{l}0.016 \\
(0.3)\end{array}$ \\
\hline sector 5 & $\begin{array}{c}-0.021 \\
(-1.15)\end{array}$ & $\begin{array}{c}0.230 \\
(5) * * *\end{array}$ & $\begin{array}{c}0.237 \\
(4.96) * * *\end{array}$ & $\begin{array}{c}0.044 \\
(0.89)\end{array}$ \\
\hline sector 6 & $\begin{array}{c}0.010 \\
(1.26)\end{array}$ & $\begin{array}{c}0.045 \\
(2.18) * *\end{array}$ & $\begin{array}{c}0.049 \\
(2.29) * *\end{array}$ & $\begin{array}{c}0.023 \\
(1.12)\end{array}$ \\
\hline sector 7 & $\begin{array}{c}0.019 \\
(3.39) * * *\end{array}$ & $\begin{array}{c}-0.008 \\
(-0.57)\end{array}$ & $\begin{array}{c}-0.013 \\
(-0.87)\end{array}$ & $\begin{array}{c}-0.019 \\
(-1.35)\end{array}$ \\
\hline sector 8 & $\begin{array}{c}0.020 \\
(3.49) * * *\end{array}$ & $\begin{array}{c}0.037 \\
(2.49) * *\end{array}$ & $\begin{array}{c}0.022 \\
(1.43)\end{array}$ & $\begin{array}{c}-0.004 \\
(-0.27)\end{array}$ \\
\hline situation 2 & $\begin{array}{c}0.061 \\
(6.16) * * *\end{array}$ & $\begin{array}{c}0.010 \\
(0.38)\end{array}$ & $\begin{array}{c}0.026 \\
(1.01)\end{array}$ & $\begin{array}{c}-0.072 \\
(-2.68) * * *\end{array}$ \\
\hline situation 3 & $\begin{array}{c}0.071 \\
(6.33) * * *\end{array}$ & $\begin{array}{c}-0.045 \\
(-1.57)\end{array}$ & $\begin{array}{l}-0.020 \\
(-0.67)\end{array}$ & $\begin{array}{c}-0.048 \\
(-1.56)\end{array}$ \\
\hline situation 4 & $\begin{array}{c}0.051 \\
(6.31)^{* * * *}\end{array}$ & $\begin{array}{c}-0.052 \\
(-2.53) * *\end{array}$ & $\begin{array}{c}-0.032 \\
(-1.51)\end{array}$ & $\begin{array}{c}-0.034 \\
(-1.59)\end{array}$ \\
\hline situation 5 & $\begin{array}{c}0.047 \\
(5.02) * * *\end{array}$ & $\begin{array}{c}0.009 \\
(0.36)\end{array}$ & $\begin{array}{c}-0.113 \\
(-4.31) * * *\end{array}$ & $\begin{array}{c}-0.130 \\
(-4.52) * * *\end{array}$ \\
\hline situation 6 & $\begin{array}{c}0.065 \\
(2.57) * *\end{array}$ & $\begin{array}{c}0.496 \\
(7.53) * * *\end{array}$ & $\begin{array}{c}0.444 \\
(6.48) * * *\end{array}$ & $\begin{array}{c}0.484 \\
(7.78) * * *\end{array}$ \\
\hline lnbounced/liabilities & $\begin{array}{c}0.001 \\
(0.68)\end{array}$ & $\begin{array}{c}-0.013 \\
(-3.14) * * *\end{array}$ & $\begin{array}{c}-0.010 \\
(-2.49) * *\end{array}$ & $\begin{array}{c}0.007 \\
(1.92) *\end{array}$ \\
\hline guarantees $=1$ & $\begin{array}{c}0.008 \\
(1.86) *\end{array}$ & $\begin{array}{c}-0.011 \\
(-0.98)\end{array}$ & $\begin{array}{l}0.006 \\
(0.5)\end{array}$ & $\begin{array}{c}-0.071 \\
(-6.58) * * *\end{array}$ \\
\hline foreign bank $=1$ & $\begin{array}{c}0.013 \\
(2.95) * * *\end{array}$ & $\begin{array}{c}0.039 \\
(3.37) * * *\end{array}$ & $\begin{array}{c}0.054 \\
(4.46) * * *\end{array}$ & $\begin{array}{c}0.096 \\
(8.58) * * *\end{array}$ \\
\hline public bank $=1$ & $\begin{array}{c}-0.003 \\
(-0.38)\end{array}$ & $\begin{array}{c}0.044 \\
(2.43) * *\end{array}$ & $\begin{array}{c}0.069 \\
(3.71) * * *\end{array}$ & $\begin{array}{c}-0.188 \\
(-8.78) * * *\end{array}$ \\
\hline wholesale bank $=1$ & $\begin{array}{c}0.019 \\
(2.24) * *\end{array}$ & $\begin{array}{c}0.107 \\
(5.02) * * *\end{array}$ & $\begin{array}{c}0.091 \\
(4.1) * * *\end{array}$ & $\begin{array}{c}-0.007 \\
(-0.34)\end{array}$ \\
\hline bank's market share & $\begin{array}{c}0.000 \\
(0.12)\end{array}$ & $\begin{array}{c}0.000 \\
(0.13)\end{array}$ & $\begin{array}{c}0.000 \\
(-0.04)\end{array}$ & $\begin{array}{c}-0.017 \\
(-10.56) * * *\end{array}$ \\
\hline liabilities bank/system & $\begin{array}{c}0.038 \\
(3.62) * * *\end{array}$ & $\begin{array}{c}0.266 \\
(9.96) * * *\end{array}$ & $\begin{array}{c}0.347 \\
(12.2)^{* * *}\end{array}$ & $\begin{array}{c}0.084 \\
(3.04) * * *\end{array}$ \\
\hline no. banks & $\begin{array}{c}0.004 \\
(4.26) * * *\end{array}$ & $\begin{array}{c}0.035 \\
(14.72) * * *\end{array}$ & $\begin{array}{c}0.041 \\
(16.52) * * *\end{array}$ & $\begin{array}{c}0.020 \\
(8.43) * * *\end{array}$ \\
\hline no. credit lines & $\begin{array}{c}0.001 \\
(0.47)\end{array}$ & $\begin{array}{c}0.010 \\
(2.25) * *\end{array}$ & $\begin{array}{c}0.024 \\
(5.03) * * *\end{array}$ & $\begin{array}{c}0.084 \\
(18.32) * * *\end{array}$ \\
\hline - cons & $\begin{array}{c}0.181 \\
(11.22) * * *\end{array}$ & $\begin{array}{c}1.026 \\
(24.77) * * *\end{array}$ & $\begin{array}{c}0.876 \\
(20.27) * * *\end{array}$ & $\begin{array}{c}0.230 \\
(5.48) * * *\end{array}$ \\
\hline Number of obs & 5,860 & 5,860 & 5,860 & 5,860 \\
\hline LR chi2 & 851 & 1,528 & 1,514 & 1,263 \\
\hline Prob $>$ chi2 & 0.00 & 0.00 & 0.00 & 0.00 \\
\hline Pseudo R2 & -0.17 & 0.22 & 0.21 & 0.24 \\
\hline Log likelihood & 2,810 & $-2,660$ & $-2,834$ & $-1,996$ \\
\hline Estimation method & Tobit & Tobit & Tobit & Tobit \\
\hline
\end{tabular}

${ }^{+}$Validation Criteria 1/2/3/5/7/13.

Note: $t$-statistics in parenthesis. 1, 2 and 3 asterisks indicate significance at $10 \%, 5 \%$ or $1 \%$. 
Petersen and Rajan (1994) point out that estimates where the dependent variable is some measure of firm's debt ratio suffer from identification problems. Changes in the debt ratio can be due to changes in the demand for credit (the supply curve is observed) or to changes in the supply of credit (the demand curve is observed). For example, they expect credit availability to be greater for higher quality firms, and in this sense they find that larger firms tend to have a high debt-to-asset ratio. However, older firms and more profitable firms (which they also expect to be higher quality), have lower, not higher, debt ratios. The problem is that it is difficult to tell, say, whether older firms are rationed by creditors (a supply effect), or whether they have a lower demand for external credit. For that reason, Petersen and Rajan discard indebtedness as a measure of credit availability, turning instead to percentage of discounts on trade credit taken by the firm.

In this sense, the signs in Table 14 are very sensitive to which definition is chosen. Firms in bad credit situations tend to be highly indebted, which seems to indicate a demand factor related to financial distress. On the other hand, bank credit tends to be smaller when the credit situation deteriorates (excepting situation 6, a special technical category). This is particularly clear for overdrafts, and seems to indicate a supply effect, i.e. that firms are cut off from credit by banks. While good firms may need to resort less to overdrafts, a supply factor like willingness to lend can reduce the amount of overdrafts available to bad firms. Thus, overdrafts have the same problems of identification as indicators of indebtedness.

Another example is the sales/assets ratio. It has a positive sign in the first column, which as we shall see can be interpreted as firms with good investment opportunities having more access to credit. The negative sign for the other columns is not necessarily an inconsistency, since it could mean that the firm does not need to resort to more credit from the domestic banking system, substituting it for other forms of credit. However, if that is so, what is being measured now is a demand effect, not availability of funds. There are several other examples along these lines.

There are other complications with the use of these ratios as measures of access to credit. In accordance with the results of other studies, the debt/asset ratio rises with the size of the firm (lnassets). On the other hand, the reliance on bank credit, in any of its definitions, falls, as one would expect if SMEs are the firms most reliant on banking relationships for finance. Hence, there are composition effects. Though larger firms rely less on bank debt, they more than compensate this with non-bank sources of finance. Thus, the ratio of bank liabilities to assets, that might appear promising as a measure of access to credit because it includes not only loan drawn but also the total of loans granted, loses its appeal due to this composition effect. If we had a figure not only of actual debt, but also of overall potential credit, the picture might be different.

Though there are more things to say, our conclusion is that in Table 14 it is hard to sort out demand and supply effects. The procedure of using debt-to-assets ratios to estimate access to credit is the one usually used in the applied literature. A series of instruments and econometric procedures are applied to get around the simultaneity problems. In this regard, Gallego and Loayza (2000) have a study that represents current best practice.

We propose a different procedure to get around these problems. We single out unused credit lines, something that can be related to Petersen and Rajan's idea of why "Discounts 
Taken" is informative in relation to credit constraints. Their firms had the possibility of using trade credit to finance their purchases, paying 20 days later forsaking a $2 \%$ discount. If a firm decides to pay earlier to get a discount, it has a less expensive credit line available in the financial system. Alternatively, it could also have lots of cash at hand so its demand of external funds is low. The measure of percentage of discounts taken on trade credits devised by Petersen and Rajan (1994) does not isolate demand and supply factors. What it achieves, instead, is an indicator that is not affected in the same direction by both factors. Better quality firms are offered more credit in the financial system, so for supply reasons these firms have to resort less to trade credit. But if a firm demanded more funds, it would eventually have to resort more to trade credit, so this cannot be confused with an outward supply shift, as could happen with the figures on indebtedness discussed above. Therefore, a dependent variable that had that same behavior as discounts taken could work. Unused credit lines does just that.

\subsection{Proportion of unused credit lines in main bank}

To avoid the problems that leverage presents as a measure of availability of credit, we turn to unused credit lines in the financial system. In principle this indicates not how much credit a firm has used, but rather how much it has available through loan commitment contracts.

We started to work with unused credit lines at the system level. However, we prefer to focus here on an alternative formulation where the dependent variable is the portion of unused credit lines in the main bank, i.e. the bank where the largest share of liabilities are concentrated. The characteristics of the lender correspond to the main bank, except for the few cases two banks were tied in first place, when we included both. This allows a better estimation of the effect of the relationship variables, since variables taken from the main bank are weaker explaining available credit lines on a system-wide basis, and it makes no sense to define some of our relationship variables in terms of the whole system.

Our hypothesis was that unused credit lines indicated a firm that was not credit constrained, while the opposite meant a firm that was. Therefore, the estimation should consider both zeros and the non-zero unused credit lines, because both were informative. The formulation to capture the access to credit is the amount of unused credit lines granted by financial institutions to firms is thus:

\section{Unused Credit Line in Main Bank $=\beta_{0}+\beta_{1}$ Firm specific information $+\beta_{2}$ Industry dummies + $\beta_{3}$ loan and lender characteristics $+\beta_{4}$ Credit history $+\beta_{5}$ Measure of relationships $+\varepsilon_{0}$}

We used a standard two-part selection model. ${ }^{4}$ The model was estimated by both full information maximum likelihood and the Heckman two-step procedure. On one hand, the likelihood function for the normal selection model is well known to be numerically difficult to handle, which calls for two-stage type methods. On the other hand, as in the case of this paper,

\footnotetext{
${ }^{4}$ Initially, since the dependent variable is limited to the [0,1] closed interval, parameters were estimated as in Petersen and Rajan (1994) using a two-limit Tobit specification. This specification implicitly assumes, in terms of the general selectivity model, that the regression equation is also the selection equation. In this final version, by allowing these two equations to differ we can distinguish between two effects. First, what determines whether a firm has an unused credit line or not (a 0/1 decision). Second, of those firms with unused credit lines, what determines the amount of unused credit lines. The determinants turn out to be similar in both steps. Hence, at least qualitatively, results of the selectivity model replicate those of our initial two-limit Tobit specification.
} 
when the selection equation shares many explanatory variables with the regression equation, the identification of the second stage of Heckman's method may suffer from a very high multicollinearity between the explanatory variables in the regression equation and the additional regressor included to correct for the selection bias. We used both methods to handle this issue and compare estimation results. We show the results of the Heckman two-step procedure, but estimates using both methods do not differ substantially (see Nawata and Nagase, 1996, for more details on estimating selection models). Consistent standard errors for the selection model are computed as in Greene (1997, p. 981).

Table 15 presents the results of the regression equation, while the selection equation is relegated to Appendix E1.

\section{Table 15}




\begin{tabular}{|c|c|c|c|c|}
\hline \multicolumn{5}{|c|}{ Unused Credit Ratio Regression Equations: Different Sub-samples } \\
\hline Explanatory variables & Contitob & Contitotb $^{+}$ & Contitotb $^{++}$ & Contitotb $^{+++}$ \\
\hline roa & $\begin{array}{r}0.003 \\
(0.88)\end{array}$ & $\begin{array}{c}0.002 \\
(0.48)\end{array}$ & $\begin{array}{r}0.119 \\
(1.14)\end{array}$ & $\begin{array}{c}0.140 \\
(1.78) *\end{array}$ \\
\hline lnassets & $\begin{array}{c}0.063 \\
(5.16) * * *\end{array}$ & $\begin{array}{c}0.083 \\
(11.05) * * *\end{array}$ & $\begin{array}{c}0.096 \\
(7.78) * * *\end{array}$ & $\begin{array}{c}0.090 \\
(8.81)^{* * *}\end{array}$ \\
\hline lnsales/assets & $\begin{array}{c}0.117 \\
(4.5) * * *\end{array}$ & $\begin{array}{c}0.147 \\
(5.5) * * *\end{array}$ & $\begin{array}{c}0.100 \\
(2.1) * *\end{array}$ & $\begin{array}{c}0.105 \\
(2.73) * * *\end{array}$ \\
\hline lndebt/assets & $\begin{array}{c}-0.096 \\
(-1.8) *\end{array}$ & $\begin{array}{c}-0.130 \\
(-2.32) * *\end{array}$ & $\begin{array}{c}-0.279 \\
(-2.25) * *\end{array}$ & $\begin{array}{c}-0.253 \\
(-2.54) * *\end{array}$ \\
\hline sector 0 & $\begin{array}{r}-0.045 \\
(-0.94)\end{array}$ & $\begin{array}{c}0.000 \\
(-0.01)\end{array}$ & $\begin{array}{r}-0.022 \\
(-0.29)\end{array}$ & $\begin{array}{r}-0.047 \\
(-0.86)\end{array}$ \\
\hline sector 1 & $\begin{array}{c}-0.269 \\
(-4.25) * * *\end{array}$ & $\begin{array}{c}-0.222 \\
(-6.44) * * *\end{array}$ & $\begin{array}{c}-0.222 \\
(-3.71)^{* * *}\end{array}$ & $\begin{array}{c}-0.219 \\
(-4.47) * * *\end{array}$ \\
\hline sector 3 & $\begin{array}{c}0.104 \\
(1.03)\end{array}$ & $\begin{array}{r}0.145 \\
(1.37)\end{array}$ & $\begin{array}{c}0.286 \\
(1.71)^{*}\end{array}$ & $\begin{array}{r}0.204 \\
(1.43)\end{array}$ \\
\hline sector 5 & $\begin{array}{r}-0.055 \\
(-0.54)\end{array}$ & $\begin{array}{l}-0.085 \\
(-0.8)\end{array}$ & $\begin{array}{c}-0.042 \\
(-0.29)\end{array}$ & $\begin{array}{c}-0.065 \\
(-0.48)\end{array}$ \\
\hline sector 6 & $\begin{array}{r}-0.026 \\
(-0.59)\end{array}$ & $\begin{array}{r}-0.007 \\
(-0.16)\end{array}$ & $\begin{array}{c}0.002 \\
(0.03)\end{array}$ & $\begin{array}{c}-0.036 \\
(-0.62)\end{array}$ \\
\hline sector 7 & $\begin{array}{c}-0.083 \\
(-1.67)^{*}\end{array}$ & $\begin{array}{c}-0.092 \\
(-2.89) * * *\end{array}$ & $\begin{array}{l}-0.070 \\
(-1.42)\end{array}$ & $\begin{array}{c}-0.092 \\
(-2.2) * *\end{array}$ \\
\hline sector 8 & $\begin{array}{c}-0.068 \\
(-1.42)\end{array}$ & $\begin{array}{c}-0.069 \\
(-2.14) * *\end{array}$ & $\begin{array}{c}-0.063 \\
(-1.25)\end{array}$ & $\begin{array}{c}-0.081 \\
(-1.9)^{*}\end{array}$ \\
\hline situation 2 & $\begin{array}{c}-0.299 \\
(-5.17) * * *\end{array}$ & $\begin{array}{c}-0.259 \\
(-4.58) * * *\end{array}$ & $\begin{array}{c}-0.286 \\
(-2.78) * * *\end{array}$ & $\begin{array}{c}-0.257 \\
(-2.8) * * *\end{array}$ \\
\hline situation 3 & $\begin{array}{c}-0.457 \\
(-5.58) * * *\end{array}$ & $\begin{array}{c}-0.461 \\
(-5.61)^{* * *}\end{array}$ & $\begin{array}{c}-0.663 \\
(-4.44) * * *\end{array}$ & $\begin{array}{c}-0.617 \\
(-4.6) * * *\end{array}$ \\
\hline situation 4 & $\begin{array}{c}-0.774 \\
(-7.2)^{* * *}\end{array}$ & $\begin{array}{c}-0.790 \\
(-10.2) * * *\end{array}$ & $\begin{array}{c}-0.845 \\
(-6.97) * * *\end{array}$ & $\begin{array}{c}-0.802 \\
(-7.17) * * *\end{array}$ \\
\hline situation 5 & $\begin{array}{c}-0.773 \\
(-5.73) * * *\end{array}$ & $\begin{array}{c}-0.730 \\
(-7.05)^{* * *}\end{array}$ & $\begin{array}{c}-0.804 \\
(-5.01) * * *\end{array}$ & $\begin{array}{c}-0.778 \\
(-5.39) * * *\end{array}$ \\
\hline situation 6 & $\begin{array}{c}-0.606 \\
(-2.85) * * *\end{array}$ & $\begin{array}{c}-0.720 \\
(-2.89) * * *\end{array}$ & $\begin{array}{c}-0.388 \\
(-1.51)\end{array}$ & $\begin{array}{r}-0.395 \\
(-1.56)\end{array}$ \\
\hline lnbounced/liabilities & $\begin{array}{c}-0.040 \\
(-3.61)^{* * *}\end{array}$ & $\begin{array}{c}-0.047 \\
(-4.29) * * *\end{array}$ & $\begin{array}{c}-0.047 \\
(-2.24) * *\end{array}$ & $\begin{array}{c}-0.038 \\
(-2.26) * *\end{array}$ \\
\hline guarantees/liabilities & $\begin{array}{c}0.427 \\
(8.25) * * *\end{array}$ & $\begin{array}{c}0.429 \\
(8.27) * * *\end{array}$ & $\begin{array}{c}0.475 \\
(5.3) * * *\end{array}$ & $\begin{array}{c}0.475 \\
(6.1) * * *\end{array}$ \\
\hline foreign bank=1 & $\begin{array}{l}-0.012 \\
(-0.4)\end{array}$ & $\begin{array}{c}-0.022 \\
(-0.86)\end{array}$ & $\begin{array}{r}0.007 \\
(0.16)\end{array}$ & $\begin{array}{r}-0.003 \\
(-0.08)\end{array}$ \\
\hline public bank $=1$ & $\begin{array}{c}0.069 \\
(2.15) * *\end{array}$ & $\begin{array}{c}0.061 \\
(1.74) *\end{array}$ & $\begin{array}{c}0.081 \\
(1.32)\end{array}$ & $\begin{array}{r}0.057 \\
(1.11)\end{array}$ \\
\hline wholesale bank $=1$ & $\begin{array}{c}0.247 \\
(5.38) * * *\end{array}$ & $\begin{array}{c}0.259 \\
(5.18) * * *\end{array}$ & $\begin{array}{c}0.293 \\
(4.24) * * *\end{array}$ & $\begin{array}{c}0.303 \\
(4.75) * * *\end{array}$ \\
\hline bank's market share & $\begin{array}{c}0.029 \\
(5.84)^{* * *}\end{array}$ & $\begin{array}{c}0.032 \\
(9.09) * * *\end{array}$ & $\begin{array}{c}0.032 \\
(5.86) * * *\end{array}$ & $\begin{array}{c}0.035 \\
(7.31)^{* * * *}\end{array}$ \\
\hline liabilities bank/system & $\begin{array}{c}0.214 \\
-\end{array}$ & $\begin{array}{c}0.197 \\
(3.2) * * *\end{array}$ & $\begin{array}{c}0.238 \\
(2.43) * *\end{array}$ & $\begin{array}{c}0.187 \\
(2.27) * *\end{array}$ \\
\hline no. banks & $\begin{array}{c}-0.027 \\
(-7.28) * * *\end{array}$ & $\begin{array}{c}-0.031 \\
(-5.45) * * *\end{array}$ & $\begin{array}{c}-0.030 \\
(-3.92) * * *\end{array}$ & $\begin{array}{c}-0.033 \\
(-4.7) * * *\end{array}$ \\
\hline no. credit lines & $\begin{array}{c}0.132 \\
(6.9) * * *\end{array}$ & $\begin{array}{c}0.129 \\
(12.91)^{* * *}\end{array}$ & $\begin{array}{c}0.124 \\
(8) * * *\end{array}$ & $\begin{array}{c}0.115 \\
(8.73)^{* * * *}\end{array}$ \\
\hline _cons & $\begin{array}{c}-1.394 \\
-\end{array}$ & $\begin{array}{c}-1.582 \\
(-16.5) * * *\end{array}$ & $\begin{array}{c}-1.646 \\
(-10.74) * * *\end{array}$ & $\begin{array}{c}-1.523 \\
(-11.82)^{* * *}\end{array}$ \\
\hline Number of obs & 15,822 & 11,772 & 4,426 & 5,860 \\
\hline Censored obs & 11,679 & 8,242 & 3,078 & 3,998 \\
\hline Uncensored obs & 4,143 & 3,530 & 1,348 & 1,862 \\
\hline Wald chi2 & 4,186 & 876 & 380 & 481 \\
\hline Prob > chi2 & 0.00 & 0.00 & 0.00 & 0.00 \\
\hline Log likelihood & $-8,313$ & $-6,880$ & $-2,629$ & $-3,514$ \\
\hline Estimation method & Heckman sel. mod. & Heckman sel. mod. & Heckman sel. mod. & Heckman sel. mod. \\
\hline
\end{tabular}


In regard to firm characteristics, the availability of credit is positively and significantly associated with the amount of assets (lnassets), with the sales/assets ration (lnsales/assets), and -in the last regression equation-- with the return on assets (roa), and it is negatively and significantly associated with the debt-to-assets ratio (Indebt/assets). At the main bank, a worse credit situation (situation*) is negatively and significantly associated to less credit availability, and the same happens with bounced checks (Inbounced/liabilities). The relationship variables show that credit availability is positively and significantly associated with more debt concentration in the main bank (liabilities bank/system), and with the use of more accounts at the main bank (no. credit lines), and it is negatively and significantly associated with the number of banks (no. banks). Finally, more collateral (guarantees/liabilities), and having a main bank that is wholesale (wholesale bank) or large (bank's market share) is significantly related to more credit availability.

We want to clarify some issues related to the interpretation of these results. Petersen and Rajan divide firm characteristics into investment opportunities, which should reduce credit availability, and measures of cash flow, which should increase it. They admit that the dividing line is not always clear, and the effect may be a priori ambiguous, e.g. return over assets and sales over assets can be considered either as measures of internal cash flow, or as measures of investment opportunities. However, these distinctions may not matter at all: if banks see this characteristic of larger investment opportunities, they may be willing to lend more. Indeed, as Galindo, Schiantarelli, and Weiss (2001) show, an efficient financial system will try to channel funds to firms with more profitable investment opportunities. The proxies they use for investment opportunities are precisely return over assets and sales over assets, precisely the variables that Petersen and Rajan consider might reduce credit availability. As far as these investment opportunities are common knowledge to both parts, because they can be inferred from the accounting statements of firms, this should increase the supply of funds coming from profit maximizing financial institutions. Hence, these arguments should lead one to expect return over assets and sales over assets to unambiguously increase the availability of credit, exactly what happens in our estimates.

A possible stumbling block with our conjecture is that good firms with a lot of cash might not have unused credit lines simply because they do not need them, so they do not apply for line of credit contracts in the first place. In this regard, large firms immediately come to mind, since they are identified in the literature with good quality firms. By the way, it is known that larger firms are firms that are less likely to be credit constrained (Schiantarelli, 1996). However, Table 15 with the regression equation shows that larger firms have more unused credit lines available than small firms (large firms are also more likely to not have zero unused credit lines, according to the selection equation in the Appendix). This happens despite the fact that large firms in Argentina might have fewer incentives to sign loan commitment contracts with domestic banks, because they usually need to resort less to the domestic financial system because of their access to cheaper credit abroad. This seems to support our conjecture that firms that are not credit constrained have unused bank credit available.

It remains to see if this result is robust in other datasets. For instance, if our measure of unused credit lines is introduced into the interest rate regressions, it is significantly and negatively related to marginal interest rates. This is sensible if one thinks that firms that are cut off from credit in their main bank have to go shopping to other banks that are more expensive. However, using data from the Italian Centrale dei Rischi, which distinguishes between banks 
loans granted and bank loans drawn, D’Auria, Foglia, and Marullo-Reedtz (1999) find the opposite. The share of loans drawn is negatively related to the rate of interest, which means that firms with less unused credit lines pay lower interest rates. A difference between their study and ours is that we look at the interest rate in the marginal bank, whereas they explain the interest rate at each bank, and see the effect of unused credit lines available in that same bank. However, a priori we would also have expected a firm to exhaust its cheaper sources of funds in a bank first, so it is hard to make sense of their results on the cost of credit. In summary, though the proportion of unused credit lines in total bank liabilities might be easier to replicate for a wider number of countries than the indirect measures drawn from trade credit by Petersen and Rajan (1994), it remains to be seen if unused bank credit turns out to be a sensible indicator of credit availability, as seems to be the case for the firms in our sample from Argentina.

As in the case of the cost of credit, we re-estimated the regression equations with some additional explanatory variables. The selection equation is in Appendix E.2.

\section{Table 16}




\begin{tabular}{|c|c|c|c|c|}
\hline \multicolumn{5}{|c|}{ Unused Credit Ratio Regression Equations: Additional Variables } \\
\hline Explanatory variables & Contitotb ${ }^{+++}$ & Contitotb $^{+++}$ & Contitotb $^{\text {+f+ }}$ & Contitotb $^{+++}$ \\
\hline \multirow[t]{2}{*}{ roa } & 0.140 & 0.134 & 0.142 & 0.141 \\
\hline & $(1.78)^{*}$ & $(1.72)^{*}$ & $(1.82)^{*}$ & $(1.85)^{*}$ \\
\hline \multirow[t]{2}{*}{ lnassets } & 0.090 & 0.086 & 0.086 & 0.086 \\
\hline & $(8.81)^{* * *}$ & $(8.45)^{* * *}$ & $(8.43) * * *$ & $(8.64)^{* * *}$ \\
\hline \multirow[t]{2}{*}{ Insales/assets } & 0.105 & 0.104 & 0.103 & 0.100 \\
\hline & $(2.73) * * *$ & $(2.73) * * *$ & $(2.68) * * *$ & $(2.67)^{* * *}$ \\
\hline \multirow[t]{2}{*}{ Indebt/assets } & -0.253 & -0.249 & -0.248 & -0.240 \\
\hline & $(-2.54) * *$ & $(-2.52) * *$ & $(-2.51) * *$ & $(-2.49)^{* *}$ \\
\hline \multirow[t]{2}{*}{ sector 0} & -0.047 & -0.049 & -0.051 & -0.056 \\
\hline & $(-0.86)$ & $(-0.91)$ & $(-0.95)$ & $(-1.06)$ \\
\hline \multirow[t]{2}{*}{ sector 1} & -0.219 & -0.220 & -0.221 & -0.223 \\
\hline & $(-4.46) * * *$ & $(-4.5) * * *$ & $(-4.51) * * *$ & $(-4.66) * * *$ \\
\hline \multirow[t]{2}{*}{ sector 3} & 0.204 & 0.207 & 0.210 & 0.210 \\
\hline & (1.43) & $(1.46)$ & (1.48) & (1.51) \\
\hline \multirow[t]{2}{*}{ sector 5} & -0.065 & -0.058 & -0.059 & -0.069 \\
\hline & $(-0.48)$ & $(-0.43)$ & $(-0.44)$ & $(-0.52)$ \\
\hline \multirow[t]{2}{*}{ sector 6} & -0.036 & -0.022 & -0.021 & -0.017 \\
\hline & $(-0.62)$ & $(-0.38)$ & $(-0.36)$ & $(-0.3)$ \\
\hline \multirow[t]{2}{*}{ sector 7} & -0.092 & -0.089 & -0.089 & -0.091 \\
\hline & $(-2.2) * *$ & $(-2.12) * *$ & $(-2.14) * *$ & $(-2.22)^{* *}$ \\
\hline \multirow[t]{2}{*}{ sector 8} & -0.081 & -0.076 & -0.077 & -0.080 \\
\hline & $(-1.9) *$ & $(-1.78) *$ & $(-1.81) *$ & $(-1.91)^{*}$ \\
\hline \multirow[t]{2}{*}{ situation 2} & -0.257 & -0.235 & -0.305 & -0.300 \\
\hline & $(-2.8) * * *$ & $(-2.57) * * *$ & $(-2.98) * * *$ & $(-2.99) * * *$ \\
\hline situation 3 & -0.617 & -0.578 & -0.618 & -0.599 \\
\hline & $(-4.6) * * *$ & $(-4.32) * * *$ & $(-4.36) * * *$ & $(-4.32) * * *$ \\
\hline situation 4 & -0.802 & -0.730 & -0.745 & -0.716 \\
\hline & $(-7.17) * * *$ & $(-6.41) * * *$ & $(-6.49) * * *$ & $(-6.38) * * *$ \\
\hline situation 5 & -0.778 & -0.743 & -0.788 & -0.772 \\
\hline & $(-5.39) * * *$ & $(-5.16) * * *$ & $(-5.37) * * *$ & $(-5.39) * * *$ \\
\hline situation 6 & -0.395 & -0.353 & -0.453 & -0.438 \\
\hline & $(-1.56)$ & $(-1.4)$ & $(-1.74)^{*}$ & $(-1.72)^{*}$ \\
\hline Inbounced/liabilities & -0.038 & -0.024 & -0.022 & -0.022 \\
\hline & $(-2.26)^{* *}$ & $(-1.45)$ & $(-1.29)$ & $(-1.31)$ \\
\hline guarantees/liabilities & 0.475 & 0.474 & 0.473 & 0.477 \\
\hline & $(6.1) * * *$ & $(6.12)^{* * *}$ & $(6.09) * * *$ & $(6.3)^{* * *}$ \\
\hline foreign bank $=1$ & -0.003 & -0.005 & -0.004 & 0.003 \\
\hline & $(-0.08)$ & $(-0.13)$ & $(-0.12)$ & $(0.08)$ \\
\hline public bank $=1$ & 0.057 & 0.060 & 0.061 & 0.065 \\
\hline & $(1.11)$ & $(1.16)$ & (1.19) & $(1.29)$ \\
\hline wholesale bank $=1$ & 0.303 & 0.307 & 0.307 & 0.301 \\
\hline & $(4.75) * * *$ & $(4.83) * * *$ & $(4.81) * * *$ & $(4.84)^{* * *}$ \\
\hline bank's market share & 0.035 & 0.034 & 0.034 & 0.032 \\
\hline & $(7.31) * * *$ & $(7.17) * * *$ & $(7.14) * * *$ & $(6.97)^{* * *}$ \\
\hline liabilities bank/system & 0.187 & 0.175 & 0.177 & 0.055 \\
\hline & $(2.27) * *$ & $(2.13) * *$ & $(2.15) * *$ & $(0.61)$ \\
\hline no. banks & -0.033 & -0.031 & -0.031 & -0.071 \\
\hline & $(-4.7) * * *$ & $(-4.42) * * *$ & $(-4.41) * * *$ & $(-4.47)^{* * *}$ \\
\hline no. credit lines & 0.115 & 0.114 & 0.114 & 0.112 \\
\hline & $(8.73) * * *$ & $(8.66) * * *$ & $(8.67) * * *$ & $(8.64)^{* * *}$ \\
\hline _cons & -1.523 & -1.470 & -1.471 & -1.258 \\
\hline & $(-11.82)^{* * *}$ & $(-11.43) * * *$ & $(-11.41) * * *$ & $(-9.07)^{* * *}$ \\
\hline bounced other bank $=1$ & - & -0.192 & -0.193 & -0.183 \\
\hline & - & $(-3.45) * * *$ & $(-3.44) * * *$ & $(-3.34) * * *$ \\
\hline system situation $(-1,0,1)$ & - & - & -0.127 & -0.130 \\
\hline & - & - & $(-1.72)^{*}$ & $(-1.8)^{*}$ \\
\hline no. banks square & - & - & - & 0.002 \\
\hline & - & - & - & $(2.85)^{* * *} *$ \\
\hline Number of observations & 5,860 & 5,860 & 5,860 & 5,860 \\
\hline Censored obs & 3,998 & 3,998 & 3,998 & 3,998 \\
\hline Uncensored obs & 1,862 & 1,862 & 1,862 & 1,862 \\
\hline Wald chi2 & 481 & 490 & 488 & 496 \\
\hline Prob > chi2 2 & 0.00 & 0.00 & 0.00 & 0.00 \\
\hline Log likelihood & $-3,514$ & $-3,497$ & $-3,495$ & $-3,457$ \\
\hline Estimation method & Heckman sel. mod. & Heckman sel. mod. & Heckman sel. mod. & Heckman sel. mod \\
\hline
\end{tabular}


To control for a possible non-linearity of number of banks, we introduced a quadratic term. This term was positive and significant. Simulating the composite effect of changing the number of banks, one finds the following:

Table 17

\begin{tabular}{|l|c|c|}
\hline \multicolumn{2}{|c|}{ Effect of Number of Banks on Credit Availability } \\
\hline Percentile & no. banks & Composite effect \\
\hline 1 & 1 & -0.069 \\
5 & 1 & -0.069 \\
10 & 1 & -0.069 \\
25 & 2 & -0.134 \\
50 & 3 & -0.195 \\
75 & 6 & -0.354 \\
90 & 8 & -0.44 \\
95 & 10 & -0.51 \\
99 & 15 & -0.615 \\
\hline
\end{tabular}

Source: Table 16, regression four.

The negative effect of banks on available credit increases as the number of banks rises, reaching a minimum when no. banks $=18$. After that, the value starts rising. However, $99 \%$ of the firms operate with 15 banks or less.

The dummy for bounced checks in other banks is significant and negative, but it makes the bounced checks in the main bank lose significance. The variable on system situation is significant, indicating that if the median rating in the system is worse, then available credit in the main bank is smaller, and if it is rated better, available credit is larger (we did not create two separate variables, to see if effects were asymmetric). This suggests that the credit situations reported in Central de Deudores have an impact on credit constraints, and the public credit register helps to ease problems of asymmetric information.

In summary, we interpret our two-step procedure in the sense that it provides evidence that non-credit constrained firms have unused credit lines available in the financial system, and that a larger proportion of unused credit available is an indication of easier access to credit. More precisely, when the credit limits in loan commitment contracts are exhausted, the firm faces an intensive credit constraint.

\subsection{Economic significance}

We now evaluate the economic significance of the parameters that are statistically significant, using regression equation 3 of Table 16 to estimate the impacts on the access to credit, and regression 3 in Table 13 to estimate the impacts on the cost of credit.

Table 18 presents the economic significance of the parameters estimated using the quantity regression, where the first column is the estimated parameter times the mean of the variable, and the second column is derived multiplying the estimated variable times the mean plus two standard deviation. For dummy variables, the table measures a switch from 0 to 1 . The dependent variable varies between zero and one.

\section{Table 18}




\begin{tabular}{|l|c|c|c|}
\hline \multicolumn{3}{|c|}{ Economic Significance of Variables Affecting Credit Availability } \\
\hline Explanatory variable & Mean * parameter & $\begin{array}{c}\text { (Mean+2 std.dev.) } \\
* \text { parameter }\end{array}$ & $\begin{array}{c}\text { Effect of } \\
\text { treatment (\%) }\end{array}$ \\
\hline roa & 0.0059 & 0.0966 & 9 \\
Inassets & 0.7276 & 1.0149 & 29 \\
Insales/assets & 0.0736 & 0.1651 & 9 \\
lndebt/assets & -0.1028 & -0.1823 & -8 \\
situation 2 & -0.3050 & & -31 \\
situation 3 & -0.6180 & & -62 \\
situation 4 & -0.7450 & & -75 \\
situation 5 & -0.7880 & & -79 \\
situation 6 & -0.4530 & 0.0914 & -45 \\
guarantees/liabilities & 0.0063 & & 9 \\
wholesale bank=1 & 0.3070 & 0.3969 & 31 \\
bank's market share & 0.1483 & 0.2114 & 25 \\
liabilities bank/system & 0.1158 & -0.3275 & 10 \\
no.banks & -0.1310 & 0.5492 & -20 \\
no. credit lines & 0.2556 & & 29 \\
bounced other bank=1 & -0.0281 & -0.0529 & -3 \\
system situation (-1,0,1) & 0.0318 & & -8 \\
\hline Soure: Calcugted & & \\
\hline
\end{tabular}

Source: Calculated using regression equation three from Table 16.

The table shows the main factor affecting the amount of credit available is the credit situation of the firm. A firm's access to credit decreases sharply when the credit situation worsens, except for situation 6 (which is a technical category that is not worse than 4 or 5). Close relationships are quite important for access to credit: there is a positive effect from doing more business with the main bank, and having a larger number of credit lines there, and a negative one of working with many banks, a signal of a more distant relationship. The no. banks variables indeed reinforces the effect of the liabilities bank/system variable. Also significant is that large firms, and firms that operate with wholesale banks and large banks (which may also provide an indication that these are prime firms) have more credit available.

Table 19 shows the economic significance of the interest rate regression parameters, measuring the price effects in basis points.

\section{Table 19}




\begin{tabular}{|c|c|c|c|}
\hline \multicolumn{4}{|c|}{ Economic Significance of Variables Affecting Cost of Credit } \\
\hline Explanatory variable & Mean * parameter & $\begin{array}{c}(\text { Mean+2 std.dev. }) \\
\text { *parameter }\end{array}$ & $\begin{array}{l}\text { Effect of } \\
\text { treatment }\end{array}$ \\
\hline roa & 0 & 6 & 6 \\
\hline lnassets & -103 & -142 & -39 \\
\hline lnsales/assets & -13 & -29 & -15 \\
\hline lndebt/assets & 19 & 32 & 13 \\
\hline situation 2 & 50 & & 50 \\
\hline situation 3 & 0 & & 0 \\
\hline situation 4 & 38 & & 38 \\
\hline situation 5 & 16 & & 16 \\
\hline situation 6 & 65 & & 65 \\
\hline lnbounced/liabilities & 3 & 21 & 19 \\
\hline unwarranted/overdrafts & 93 & 130 & 36 \\
\hline foreign bank $=1$ & 16 & & 16 \\
\hline wholesale bank $=1$ & -100 & & -100 \\
\hline bank's market share & -37 & -100 & -63 \\
\hline liabilities bank/system & -19 & -60 & -41 \\
\hline no. banks & 44 & 101 & 57 \\
\hline no. credit lines & -32 & -66 & -34 \\
\hline bounced other bank $=1$ & 30 & & 30 \\
\hline system situation $(-1,0,1)$ & 0 & -3 & -3 \\
\hline
\end{tabular}

SourceCalculated using regression three from Table 13.

Though we have not emphasized lender characteristics, the main explanatory factor is whether a firm works with a wholesale bank or not, which is related to a reduction of 100 basis points in the interest rate. Many wholesale banks tend to work with affiliates of multinational corporations, so this may capture characteristics of the clients they chose. Working with a large bank in also very important to get lower rates. Hence, getting to be a client of the right type of bank seems relevant, and there seems to be some matching between types of firms and types of banks. In relation to a firm's credit situation, after passing situation 2, there is no strong punishment in terms of interest rates (situation 6 is a special technical category for firms in arrears with failed banks). Bounced checks lead to appreciably more expensive credit. Relationship variables are again quite important, despite the fact that we control for credit history (authors such as Greene, 1992, expect that variable to wipe out the significance of other types of information in credit scoring).

The joint information from Tables 17 and 18 suggests the existence of equilibrium credit constraints in Argentina's formal credit market. The parameters for a firm's situation variable suggest that the firm faces a quantity effect that is stronger than the price effect as the credit situation deteriorates. The relationship variables affect appreciably both quantities and prices. A close relationship is related to more access to credit and to lower marginal interest rates.

\section{Implications of this study}

We built a cross-section of data for October 2000 to study the variation of both the cost of credit and the access of firms to credit. We study in particular how banks use different pieces of private and public information to screen firms and overcome informational asymmetries in the credit market. Some private information is transferable, like balance sheet data. Private information generated in relationships is not. We also consider public information available in the Central de Deudores. 
We use something very specific to measure the marginal cost of credit, the interest rate charged on marginal (most expensive) bank overdrafts. To measure access of firms to credit, our first intention was to use percentage of authorized overdrafts effectively drawn. The overdraft authorizations are a loan commitment contract or credit line. However, we then came up with a more comprehensive measure, unused credit lines over total financial system liabilities. This is obverse side of trade credit if, as Petersen and Rajan conjecture, firms with credit in the financial system do not resort to trade credit and pay early, to get a discount. It also has to do with the loan commitment contracts in Melnik and Plaut (1986), in the sense that firms that have exhausted their bank commitments have to look for more expensive credit elsewhere.

We find that the cost of credit is smaller for a firm with a close relationship to the marginal bank, where a close relationship is linked to a large share of credit and a large number of accounts in the marginal bank, and to a small number of total banks. Firms with large assets, a high sales/assets ratio, and a low debt/assets ratio pay a lower interest rate at the margin. A good credit history (no debt arrears and no bounced checks) and collateral also reduce the marginal interest rate. Though credit history matters, as Greene (1992) emphasizes, it is not the only thing that matters. It does not wipe out the significance of the relationship variables, which are extremely important.

Using the proportion of unused credit lines at the main bank as a measure of firms that are not credit constrained, we find that a good credit situation increases the availability of credit, and that relationships are also very important to increase the access to credit. Our proxies for relationships might signal that banks have private information that reveals the firm is not a lemon, but rather a good credit (otherwise, why extend the firm more credit?). Our measure of unused credit lines is less ambiguous than traditional measures like leverage, which may indicate financial distress rather than availability of credit. Large assets, a high return over assets, a high sales/assets ratio, a low debt/assets ratio, a good credit history, and collateral lead to higher credit availability.

The paper does not look at the macroeconomic determinants of credit constraints. Economy-wide credit constraints that reflect the doubts about the government's prospects are reflected in the baseline interest rate charged to firms. The baseline interest rate has a premium related to the interest rate spread between Argentine government bonds and U.S. government bonds. This spread, or country risk, was on average above 750 annual basis points in October 2000. A result from credit constraint theory is that a high probability of default gives financial institutions an incentive to eliminate credit lines to the borrower. Since November 2000, the international capital market for Argentina is closed due the belief of international investors that Argentina will default on its debt. After that, the spread has fluctuated widely, reaching 3500 basis points in November 2001. This of course impacts on firms, which are mostly cut off from new credit. Hence, it is convenient to explore economy-wide determinants of credit constraints faced by firms, besides the individual determinants stressed in this study. Our regressions do not capture this result because the estimation process is a cross-section for October 2000, but this might be possible looking also at data for January 2001, after international markets were closed.

This paper can help to study the implications of the law of Habeas Data, which went into effect recently in Argentina. This law puts substantial costs on the acquisition of information by lenders, limiting credit history to 5 years and limiting the access to the database. Our study shows in particular that a good median credit situation in the Central de Deudores eases credit restrictions. A policy that restricts disclosure may end up hurting good firms. 


\section{Bibliography}

Akerlof, G. 1970. "The market for lemons: quality uncertainty and the market mechanism." Quarterly Journal of Economics. 113: 79-119.

Allen, F. 2001. "Do financial institutions matter?” Journal of Finance. 56: 1165-1175.

Berger, A., Klapper, L., and Udell, G. 2000. "The ability of banks to lend to informationally opaque small businesses." Mimeo, Federal Reserve Board.

Banco Central de la República Argentina, September 2000, Información de Entidades Financieras.

Burdisso, T., D'Amato, L., Escudé, G., and McCandless, G. 2001. "How much do SMEs borrow from the banking system in Argentina?" Mimeo, Banco Central de la República Argentina.

Caballero, R. 2000. "Macroeconomic volatility in Latin America: A conceptual framework and three case studies." Economía. 1:31-107.

Caballero, R., and Krishnamurthy, A. 1999. "Emerging markets crises: An asset market perspective". Mimeo, MIT.

Cole, R. A. 1998. "The importance of relationships to the availability of credit". Journal of Banking and Finance. 22: 959-977.

D'Auria, C., Foglia, A., and Marullo-Reedtz, P. 1999. "Bank interest rates and credit relationships in Italy." Journal of Banking and Finance. 23: 1067-1093.

Diamond, D. 1984. "Financial intermediation and delegated monitoring." Review of Economic Studies. 51: 393-414.

Diamond, D. 1991. "Monitoring and reputation: the choice between bank loans and directly placed debt." Journal of Political Economy. 99: 688-721.

Freixas, X. and Rochet, J-C. 1998. Microeconomics of Banking. Cambridge, MA, United States: MIT Press.

Galindo, A., Schiantarelli, F., and Weiss, A. 2001. "Does financial liberalization improve the allocation of investment? Micro evidence form developing countries". Mimeo.

Gallego, F. and Loayza, N. 2000. "Financial Structure in Chile: Macroeconomic Developments and Microeconomic Effects." Mimeo, World Bank.

Greene, W. 1992. "A statistical model for credit scoring." Mimeo, New York University.

Greene, W. 1997. Econometric Analysis, $3^{\text {rd }}$ edition. Prentice Hall.

Hoshi, T., Kashyap, A., and Scharfstein, D. 1990. "The role of banks in reducing the costs of financial distress in Japan." Journal of Financial Economics. 27:67-88.

Mayer, C. 1994. "The assessment: Money and banking: theory and evidence." Oxford Review of Economic Policy. 10: 1-13.

Machauer, A., and Weber, M. 2000. "Number of bank relationships: An indicator of competition, borrower quality, or just size?" Mimeo, Johann Wolfgang Goethe-Universität.

Melnik, A. and Plaut, S. 1986. "Loan Commitment Contracts, Terms of Lending, and Credit Allocation." Journal of Finance. 41: 425-435.

Nawata, K. and Nagase, N. (1996), "Estimation of sample selection bias models", Econometric Reviews, 15: 387-400.

Petersen, M. and Rajan, R. 1994. "The benefits of lender relationships: Evidence from small business data." Journal of Finance. 49: 3-37. 
Schiantarelli, F. 1996. "Financial constraints and investment: Methodological issues and international evidence." Oxford Review of Economic Policy. 12: 70-89.

Sharpe, S. 1990. "Asymmetric information, bank lending and implicit contracts: A stylized model of customer relationships." Journal of Finance. 45: 1069-1087.

Stiglitz, J. and Weiss, A. 1981. "Credit Rationing in Markets with Imperfect Information." American Economic Review. 71: 393-410.

Wilcox, R. 1997. Introduction to Robust Estimation and Hypothesis Testing. New York: Academic Press.

Williamson, S. 1987. "Costly monitoring, loan contracts, and equilibrium credit rationing." Quarterly Journal of Economics. 102: 135-145. 


\section{Appendix}

\section{A. Validation of financial statements of firms}

The Central de Deudores del Sistema Financiero of the Superintendencia de Entidades Financieras of the BCRA has monthly information on every person or firm that has a debt of at least 50 pesos in the regulated financial system (this is definition of a "debtor"). This database exists since 1997, when two databases, Principales Deudores de las Entidades Financieras (Principal Debtors of Financial Institutions) and Resto de Deudores (Other Debtors), were merged.

The information on firms is divided into two parts, corporations and partnerships/sole proprietorships. For partnerships/sole proprietorships there are only three bits of information: start of activity, yearly income, and net worth. For that reason, this paper is restricted to corporations, for which information from balance sheets and income statements is available. Balance sheet information covers the following items: assets (current and non-current), liabilities (current and non-current), and net worth. The information from income statements is on sales, and gross profits. The information is usually annual. In a few cases there is information on when a society started its activities. The principal economic activity, according to two-digit national income accounts, and data on employment are sometimes informed.

Besides the Central de Deudores, two other sources provided information on balance sheets and income statements of incorporated firms:

- source B (Base de Inspectores): balance sheets and income statements of firms reviewed by the inspectors of the Superintendencia de Entidades Financieras during inspections of financial institutions.

- source C (Calificadoras de Riesgo): balance sheets and income statements gathered by risk rating agencies, required to audit "every debtor whose debt is more than $\$ \mathrm{XX}$, or at least the greatest fifty debtors" of each financial institution. The amount $\$ \mathrm{XX}$ has varied and is set currently at \$200.000 in each financial institution. This defines the "principal debtors" (principales deudores), which are a subset of the large debtors defined below (except for some of the clients of small financial institutions). ${ }^{5}$

- source D (Central de Deudores): balance sheets and income statements on "large debtors" (grandes deudores) provided by financial institutions to the BCRA. "Large debtors" are defined as firms whose debt in the whole financial system is larger than $\$ 200.000$.

We pooled the information on large debtors and principal debtors available in sources $\mathrm{B}, \mathrm{C}$, and $\mathrm{D}$. The information from the three data sources can be consolidated thanks to a unique identification code for each debtor. This identification code is the CUIT or CUIL issued by tax authorities, or a special ID assigned by the BCRA to the debtor.

As mentioned in Section 3, previous studies had seriously questioned the quality of Source D information. In this regard, our priors were that source B was the most reliable, since the financial statements were controlled by inspectors of the BCRA. Source C was expected to be the next best. On this basis, we describe the validation process we conducted, and its results.

\footnotetext{
${ }^{5}$ Source $\mathrm{C}$ also has information on how long the relationship of the client with the financial institution has lasted, and if the client has any ownership ties with the financial institution. This specific information is available for so few firms that it was finally discarded in the econometric exercises.
} 


\section{- Validation procedure}

1) Construct a joint debtor database from sources B, C, and D. Import all registers from source $\mathrm{D}$, after the elimination of duplicate registers (duplicate: all the fields equal except for date information was reported). Idem for Sources B and C. The joint file is called conjunto_base. The starting number of registers is detailed in Table A1.

Table A1

\begin{tabular}{|l|c|c|}
\hline \multicolumn{3}{|c|}{ Elimination of Duplicate Registers } \\
\hline Source & Initial registers & Conjunto_base \\
\hline B (Base) & 2,906 & 2,906 \\
C (Calificadoras) & 61,448 & 38,050 \\
D (Deudores) & 372,013 & 91,535 \\
\hline
\end{tabular}

Source: BCRA

2) Eliminate from conjunto_base the registers with date prior to $1 / 1 / 1997$, sending them to file viejos.

3) Extract registers from source $\mathrm{C}$ with date $00 / 00 / 00$ and send them to file califo0.

4) Extract unique registers. Send those from sources B and C to file validados, with field Tipo_Valid that assigns code 8 to source B registers and code 9 to source $\mathrm{C}$ registers. The code allows an identification of the origin of the registers, to screen the information afterwards. The unique registers from source $\mathrm{D}$ are sent to file unicosD.

5) Apply an iterative validation criterion. Look for debtors with the same identification number (CUIT) and the same date of last balance sheet, comparing seven fields from the balance sheet (current, non-current, and total assets; current, non-current, and total liabilities; net worth) and one field from income statements (gross profits). The comparisons are done with a tolerance of 2, i.e. 2000 pesos, to avoid problems of rounding with decimal places:

i) If $\mathrm{B}=\mathrm{C}=\mathrm{D}$, assign code Tipo_Valid $=1$ and send to validados. The redundant information goes to file basura with Tipo_Valid=1. File basepost1 is created with the registers that remain after extracting the registers sent to validados and basura. The files validados and basura contain all the fields that exist in the different sources, not only those used to compare sources. This same procedure is repeated in the next steps.

ii) If $\mathrm{B}=\mathrm{C}$, Tipo_Valid 2.

iii) If B=D, Tipo_Valid 3 .

iv) If B different from C or D, Tipo_Valid 4.

v) If C=D, Tipo_Valid 5 .

vi) If C different from D, Tipo_Valid 6.

vii) If D1=D2 (two different financial institutions provide same information), Tipo_Valid 7. The file with the remnant registers is called basepost 7 .

viii) If basepost $7=$ calif00 or basepost7=viejos, except for date of information, Tipo_Valid 10. The date of information is taken from basepost 7 . 
6) Repeat process in point (5) for remaining debtors, all from Source D, comparing only the three balance sheet items that refer to assets, liabilities and net worth, assigning code Tipo_Valid 11 . The registers that do not pass any of the previous screens are sent to resto.

7) The information from source D that was not validated in any way was added to validados with the following codes:

i) If from file unicosD, Tipo_Valid 12.

ii) If from file resto and not comparable because balance sheet and income statements were from different dates, include most recent with Tipo_Valid 13.

iii) If from file resto where information from various institutions differed, include the information from one of the institutions at random as Tipo_Valid 14.

\section{- Evaluation of the validation process}

Table A2 shows that 17,809 debtors that resulted from the validation process. If one restricts the group to firms with positive assets, there are 17,394 firms left. These firms are the basis for our "complete sample" in the regressions.

Table A2

\begin{tabular}{|l|r|r|}
\hline \multicolumn{2}{|c|}{ Validation Criteria } \\
\hline Tipo_valid & Total & Assets $>0$ \\
\hline $1(\mathrm{~B}=\mathrm{C}=\mathrm{D})$ & 870 & 870 \\
2 (B=C) & 445 & 445 \\
3 (B=D) & 264 & 264 \\
4 (B different C or D) & 1070 & 1,050 \\
$5(\mathrm{C}=\mathrm{D})$ & 2335 & 2,335 \\
6 (C different D) & 2918 & 2,878 \\
7 (D1=D2) & 673 & 673 \\
8 (unique B) & 251 & 248 \\
9 (unique C) & 2147 & 2,071 \\
10 (problematic date) & 90 & 86 \\
11 (problematic fields) & 219 & 219 \\
12 (unique D) & 4885 & 4,642 \\
13 (updated D) & 1547 & 1,539 \\
14 (D1 different D2) & 95 & 74 \\
\hline Total & 17809 & 17394 \\
\hline
\end{tabular}

Source:BCRA.

Though our priors were that Source B was the most reliable, and Source C was the next best source, our analysis of the different types of validation led us to conclude otherwise. We considered as a bad sign a large percentage of firms with zero assets/zero net worth (Table A3), liabilities/assets $>0.9$ (Table A4), or ROA=0 (Table A5). We checked if these features had to do with the fact that some firms were in financial distress, but we ruled that out (this information is not shown here).

The most reliable sources turned out to be the cases where two or more independent sources agreed, i.e. validation criteria 1, 2, 3, 5, and (though less so) 7 . Surprisingly, the data from validation criterion 13 had a behavior similar to the previous group. This might be because when several balance sheets from Source D for different dates are available, this means that a 
financial institution regularly updates the information, which also seems to indicate that it is more careful in what it reports to the BCRA. Consequently, we considered validation criteria $1,2,3,5,7$, and 13 as the most reliable. These formed the basis for our preferred sample in the econometric estimates (validation criterion 11 is a borderline case, but we did not to include it here).

On the other hand, when sources B and C disagree with all else (validation criteria 4 and 6), they usually lead to worse results than if sources B or C are the only available reference (validation criteria 8 and 9). Therefore, we did not consider these as very reliable validation criteria. The least reliable criteria turned out to be 10,12 and 14 .

Table A3

\begin{tabular}{|c|c|c|c|c|c|}
\hline \multicolumn{6}{|c|}{$\begin{array}{c}\text { Balance sheets with zero's } \\
\text { - percentages - }\end{array}$} \\
\hline Validation criteria & Total & Assets $=0$ & Liabilities $=0$ & Net worth $=0$ & All three $=0$ \\
\hline 1 & 100 & 0.0 & 0.3 & 0.0 & 0.0 \\
\hline 2 & 100 & 0.0 & 1.6 & 0.0 & 0.0 \\
\hline 3 & 100 & 0.0 & 0.0 & 0.0 & 0.0 \\
\hline 4 & 100 & 1.9 & 3.7 & 2.1 & 1.9 \\
\hline 5 & 100 & 0.0 & 0.4 & 0.1 & 0.0 \\
\hline 6 & 100 & 1.4 & 3.6 & 1.4 & 1.3 \\
\hline 7 & 100 & 0.0 & 0.0 & 0.0 & 0.0 \\
\hline 8 & 100 & 1.2 & 14.3 & 1.2 & 1.2 \\
\hline 9 & 100 & 3.5 & 11.7 & 3.7 & 3.5 \\
\hline 10 & 100 & 4.4 & 4.4 & 4.4 & 4.4 \\
\hline 11 & 100 & 0.0 & 0.0 & 0.0 & 0.0 \\
\hline 12 & 100 & 5.0 & 5.9 & 4.9 & 4.7 \\
\hline 13 & 100 & 0.5 & 1.3 & 0.5 & 0.5 \\
\hline 14 & 100 & 22.1 & 23.2 & 18.9 & 18.9 \\
\hline Total (\%) & 100 & 2.3 & 4.4 & 2.4 & 2.2 \\
\hline Total cases & 17809 & 415 & 789 & 419 & 398 \\
\hline
\end{tabular}

Source: BCRA.

Table A4

\begin{tabular}{|l|c|c|c|c|c|}
\hline Validation & \multicolumn{5}{|c|}{ Debt / Assets } \\
criteria & Assets $>0$ & Debt/assets $>0.9$ & $\begin{array}{c}\text { Percentage of } \\
\text { total }\end{array}$ & $\begin{array}{c}\text { Percentage of } \\
\text { total }\end{array}$ \\
\hline 1 & 870 & 36 & 4 & 3 & 0.3 \\
2 & 445 & 34 & 8 & 11 & 2.5 \\
3 & 264 & 16 & 6 & 3 & 1.1 \\
4 & 1,050 & 137 & 13 & 68 & 6.5 \\
5 & 2,335 & 118 & 5 & 9 & 0.4 \\
6 & 2,878 & 264 & 9 & 41 & 1.4 \\
7 & 673 & 16 & 2 & 6 & 0.9 \\
8 & 248 & 15 & 6 & 0 & 0.0 \\
9 & 2,071 & 132 & 6 & 17 & 0.8 \\
10 & 86 & 41 & 48 & 1 & 1.2 \\
11 & 219 & 5 & 2 & 0 & 0.0 \\
12 & 4,642 & 773 & 17 & 69 & 1.5 \\
13 & 1,539 & 111 & 7 & 15 & 1.0 \\
14 & 74 & 7 & 9 & 0 & 0.0 \\
\hline Total & 17,394 & 1,705 & 10 & 243 & 1.4 \\
\hline
\end{tabular}

Source: BCRA. 
Table A5

\begin{tabular}{|l|c|c|c|c|c|c|c|}
\hline \multicolumn{9}{|c|}{ Return on Assets } \\
\hline Validation criteria & Assets $>0$ & ROA=0 & $\begin{array}{c}\text { Percentage } \\
\text { of total }\end{array}$ & ROA $<0$ & $\begin{array}{c}\text { Percentage } \\
\text { of total }\end{array}$ & $\begin{array}{c}\text { Percentage } \\
\text { ROA total }>0\end{array}$ \\
\hline 1 & 870 & 18 & 2.1 & 221 & 25.4 & 631 & 72.5 \\
2 & 445 & 30 & 6.7 & 134 & 30.1 & 281 & 63.1 \\
3 & 264 & 20 & 7.6 & 70 & 26.5 & 174 & 65.9 \\
4 & 1,050 & 118 & 11.2 & 259 & 24.7 & 673 & 64.1 \\
5 & 2,335 & 164 & 7.0 & 441 & 18.9 & 1,730 & 74.1 \\
6 & 2,878 & 544 & 18.9 & 526 & 18.3 & 1,808 & 62.8 \\
7 & 673 & 201 & 29.9 & 48 & 7.1 & 424 & 63.0 \\
8 & 248 & 99 & 39.9 & 23 & 9.3 & 126 & 50.8 \\
9 & 2,071 & 856 & 41.3 & 191 & 9.2 & 1,024 & 49.4 \\
10 & 86 & 68 & 79.1 & 1 & 1.2 & 17 & 19.8 \\
11 & 219 & 55 & 25.1 & 8 & 3.7 & 156 & 71.2 \\
12 & 4,642 & 2,181 & 47.0 & 356 & 7.7 & 2,105 & 45.3 \\
13 & 1,539 & 212 & 13.8 & 213 & 13.8 & 1,114 & 72.4 \\
14 & 74 & 46 & 62.2 & 3 & 4.1 & 25 & 33.8 \\
\hline Total & 17,394 & 4,612 & 26.5 & 2,494 & 14.3 & 10,288 & 59.1 \\
\hline
\end{tabular}

Source: BCRA.

\section{- Frequency and year of information}

We checked the frequency of the information in Table A6. It is often annual, though in some cases there are a lot of unclassified firms. In the information that was reported as quarterly, the income figures were multiplied by four to get the annual equivalents. In the other cases, no adjustments were made.

\section{Table A6}

\begin{tabular}{|l|c|c|c|c|c|c|}
\hline \multicolumn{7}{|c|}{$\begin{array}{l}\text { Balance Sheet Frequency } \\
\text { - percentages - }\end{array}$} \\
\hline Validation criteria & Not classified & Quarterly & Annual & Special & Others & Total \\
\hline 1 & 0.1 & 1.7 & 96.2 & 1.6 & 0.3 & 100 \\
2 & 0.9 & 2.0 & 91.2 & 5.8 & 0.0 & 100 \\
3 & 0.0 & 1.1 & 92.4 & 4.5 & 1.9 & 100 \\
4 & 100.0 & 0.0 & 0.0 & 0.0 & 0.0 & 100 \\
5 & 0.1 & 0.9 & 94.0 & 3.2 & 1.8 & 100 \\
6 & 0.6 & 2.8 & 72.2 & 24.4 & 0.0 & 100 \\
7 & 0.0 & 0.0 & 77.4 & 0.7 & 21.8 & 100 \\
8 & 100.0 & 0.0 & 0.0 & 0.0 & 0.0 & 100 \\
9 & 0.6 & 1.0 & 48.1 & 50.3 & 0.0 & 100 \\
10 & 0.0 & 0.0 & 74.4 & 0.0 & 25.6 & 100 \\
11 & 0.0 & 0.9 & 86.8 & 0.5 & 11.9 & 100 \\
12 & 0.0 & 0.6 & 65.9 & 2.3 & 31.2 & 100 \\
13 & 0.0 & 0.5 & 93.0 & 2.1 & 4.3 & 100 \\
14 & 0.0 & 2.7 & 64.9 & 1.4 & 31.1 & 100 \\
\hline Total (\%) & 7.7 & 1.1 & 69.4 & 11.6 & 10.2 & 100 \\
Total cases & 1,334 & 193 & 12,068 & 2,017 & 1,782 & 17,394 \\
\hline
\end{tabular}

Source: BCRA. 
Table A7 shows that most of the information is prior to year 2000. The advantage of this is that we could consider the information as predetermined, when using it as controls in the regressions in Section 4.

\section{TableA7}

\begin{tabular}{|c|c|c|c|c|c|c|}
\hline \multicolumn{7}{|c|}{$\begin{array}{c}\text { Balance Sheet Dates } \\
\text { - percentages - }\end{array}$} \\
\hline $\begin{array}{l}\text { Validation } \\
\text { criteria }\end{array}$ & 1997 & 1998 & 1999 & 2000 & $\begin{array}{l}2001 \text { or } \\
\text { beyond }\end{array}$ & Total \\
\hline 1 & 0.1 & 31.0 & 66.7 & 2.2 & 0.0 & 100.0 \\
\hline 2 & 0.7 & 33.0 & 62.2 & 4.0 & 0.0 & 100.0 \\
\hline 3 & 0.4 & 48.9 & 49.2 & 1.5 & 0.0 & 100.0 \\
\hline 4 & 0.2 & 31.4 & 62.1 & 6.3 & 0.0 & 100.0 \\
\hline 5 & 11.9 & 41.5 & 44.0 & 2.6 & 0.0 & 100.0 \\
\hline 6 & 16.2 & 36.8 & 37.9 & 9.1 & 0.0 & 100.0 \\
\hline 7 & 37.9 & 29.9 & 30.8 & 1.5 & 0.0 & 100.0 \\
\hline 8 & 1.6 & 29.0 & 62.1 & 7.3 & 0.0 & 100.0 \\
\hline 9 & 17.1 & 29.9 & 38.0 & 15.1 & 0.0 & 100.0 \\
\hline 10 & 28.7 & 14.9 & 16.1 & 3.4 & 36.8 & 100.0 \\
\hline 11 & 18.7 & 37.4 & 39.3 & 4.6 & 0.0 & 100.0 \\
\hline 12 & 43.2 & 25.6 & 24.5 & 2.8 & 3.8 & 100.0 \\
\hline 13 & 4.5 & 29.0 & 56.9 & 9.5 & 0.0 & 100.0 \\
\hline 14 & 59.5 & 31.1 & 9.5 & 0.0 & 0.0 & 100.0 \\
\hline Total (\%) & 20.4 & 31.9 & 40.4 & 6.1 & 1.2 & 100.0 \\
\hline Total cases & 3,550 & 5,552 & 7,022 & 1,059 & 211 & 17,394 \\
\hline
\end{tabular}

Source: BCRA.

\section{B. Validation of interest rates}

\section{-Raw interest rate data}

The raw information is presented in Table B1. The information is from the 103 financial institutions validated for October $2000 .^{6}$ The information refers only to the financial transactions of the 16,095 firms with both positive assets and positive potential liabilities reported by the financial system for October 2000.

\section{Table B1}

\footnotetext{
${ }^{6}$ There are 113 financial institutions in all, of which 10 were not validated.
} 


\begin{tabular}{|c|c|c|c|c|c|c|c|c|}
\hline \multicolumn{9}{|c|}{ Interest Rates Reported in October 2000} \\
\hline \multirow[b]{2}{*}{ Type of loan } & \multicolumn{4}{|c|}{ Complete (includes all interest rates) } & \multicolumn{4}{|c|}{ Complete (excludes interest rates $<=.1$ ) } \\
\hline & Mean & Median & Std deviation & Cases & Mean & Median & Std deviation & Cases \\
\hline Overdrafts & 6.3 & 1.7 & 13.2 & 23,720 & 7.9 & 2.5 & 14.4 & 18,938 \\
\hline Discounted bills - guarantee A1 & 17.3 & 2.5 & 17.2 & 21 & 18.2 & 13.5 & 17.1 & 20 \\
\hline Bills and promissory notes & 3.8 & 1.2 & 6.3 & 19,517 & 4.6 & 1.3 & 6.6 & 16,336 \\
\hline House mortgages & 2.0 & 1.0 & 3.7 & 103 & 2.4 & 1.0 & 3.9 & 86 \\
\hline Other mortgages & 3.5 & 1.0 & 6.1 & 4,589 & 5.2 & 1.3 & 6.9 & 3,085 \\
\hline Car loans & 1.5 & 1.4 & 2.5 & 660 & 1.8 & 1.5 & 2.6 & 572 \\
\hline Other pledges & 2.8 & 1.0 & 5.4 & 5,279 & 4.6 & 1.4 & 6.3 & 3,208 \\
\hline Personal & 2.1 & 1.0 & 4.6 & 1,198 & 2.4 & 1.2 & 4.8 & 1,034 \\
\hline Credit card & 7.7 & 1.9 & 13.0 & 3,283 & 11.2 & 3.2 & 14.4 & 2,259 \\
\hline Interfinancial & 4.5 & 0.8 & 15.8 & 216 & 6.5 & 0.8 & 18.8 & 149 \\
\hline To guaranteed public banks & 2.6 & 0.9 & 4.6 & 7 & 2.6 & 0.9 & 4.6 & 7 \\
\hline Other loans & 1.4 & 1.0 & 4.1 & 9,712 & 2.1 & 1.3 & 4.9 & 6,509 \\
\hline Other financial & 1.4 & 0.0 & 4.2 & 7,327 & 4.4 & 1.0 & 6.5 & 2,372 \\
\hline Leases & 1.8 & 0.4 & 4.1 & 1,323 & 3.3 & 1.3 & 5.1 & 712 \\
\hline Miscellaneous & 1.1 & 0.9 & 1.7 & 59 & 1.3 & 1.0 & 1.8 & 48 \\
\hline Small personal & 1.1 & 1.0 & 0.2 & 5 & 1.1 & 1.0 & 0.2 & 5 \\
\hline
\end{tabular}

Interest rates reported as 0.01 can mean either a zero interest rate or a missing value. To avoid this problem, we decided to exclude all interest rates smaller or equal to 0.1 from the sample. Even after correcting for this, there was a wide gap between mean and median values. Moreover, the information on interest rates typically had two modal values, one at low interest rates and another at high interest rates.

\section{- February inquiry}

Financial institutions are required to inform monthly interest rates in percentages. In January 2001, a preliminary analysis was carried out for each of the 89 financial institutions then available with data for October 2000. Histograms for the interest rates charged by each institution, by type of loan, were constructed using the observations of firms classified as "large debtors" in October $2000 .^{7}$ Of these 89 institutions, 35 financial institutions were initially marked as potentially problematic. This list was the basis for a February 2001 inquiry conducted by the Superintendencia de Entidades Financieras.

The institutions were separated into four groups.

- Group 1 of institutions with no variance in interest rates: 3 institutions, all excluded.

- Group 2 of institutions with very low interest rates: 10 institutions, of which 7 were O.K.

(mainly wholesale banks), 1 misreported units, and 2 were wrong and thus excluded.

- Group 3 of institutions with very high interest rates: 14 institutions, of which 10 misreported units (they were annual rates), and 4 were wrong and thus excluded.

- Group 4 of institutions with outliers: 8 institutions, of which we accepted 5 and excluded 3.

The inquiry conducted in relation to the 89 institutions available in January, as well as the analysis of the remaining institutions that were validated later on, lead us to give the complete 103 institutions three different treatments: eliminate 15 institutions whose rates were not reliable, transform the interest rates reported by 11 institutions from annual to monthly values, and accept the rest as monthly rates that were reasonably O.K.

\section{Classification of credit situation}

There is a database on bounced checks. This information was privy to each individual bank. Confidentiality was eliminated at the end of May 2001, when the BCRA made the information

\footnotetext{
${ }^{7}$ The set of firms finally used for October 2000 only overlaps partially with this set. The final set includes firms that were not "large debtors" in October, and some of these "large debtors" were excluded because no information on balance sheet items was available from either sources B, C, or D.
} 
publicly available. Each financial institution must also supply Central de Deudores information on the credit situation of each debtor.

In relation to credit situation, Table $C 1$ shows how debtors are ranked from 1 to 6 according to actual payments (consumer loans) or estimated repayment potential (commercial loans).

\section{Table C1}

\begin{tabular}{|l|c|c|}
\hline \multicolumn{3}{|c|}{ Credit Situation } \\
\hline Situation & Commercial loans & Consumer loans \\
\hline 1 & Normal* & Normal* \\
2 & Potential risk & Occasional arrears \\
3 & Substandard & Substandard \\
4 & High risk & Unlikely repayment \\
5 & Total loss & Total loss \\
6 & \multicolumn{2}{|c|}{ Total loss (technical provisions)** } \\
\cline { 2 - 3 }
\end{tabular}

* Normal includes all loans with Type A guarantees, which are coded as 11 .

** Total loss (technical provisions) comprises arrears with liquidated financial institutions.

The credit situation is decided by each financial institution where a given client has debt. Though the rating is done by each individual financial institution, under certain conditions ratings must be harmonized if the classification differs in more than one category among institutions (e.g., if it differs more than one situation with two institutions that represent more than $20 \%$ of the debt of that client).

Out of the 17,394 firms in our database with positive assets, 16,095 firms show up in the October 2000 data. The actual differences in the credit situation of firms, according to the reports of the 103 financial institutions available for October 2000 (from a total of 113 institutions), were as follows:

\section{Table C2}

\begin{tabular}{|l|c|c|}
\hline \multicolumn{3}{|c|}{ Maximum Differences in Reported Credit Situation* } \\
\hline Difference & Cases & Percentage \\
\hline 0 & 12,381 & 76.9 \\
1 & 1,553 & 9.7 \\
2 & 887 & 5.5 \\
3 & 687 & 4.3 \\
4 & 530 & 3.3 \\
5 & 57 & 0.4 \\
\hline Total & 16,095 & 100.0 \\
\hline
\end{tabular}

*Credit situation 11 was transformed to credit situation 1 (10 cases).

These differences in the way credit situations were accorded led us to construct a second measure, a "system" indicator of credit situation, using the median of the values informed by different institutions. 


\section{Definition of variables}

\begin{tabular}{|c|c|}
\hline \multicolumn{2}{|r|}{ Variables - Price Regressions } \\
\hline \multicolumn{2}{|l|}{ Dependant variables } \\
\hline tascor & Interest rate on overdrafts in marginal bank \\
\hline \multicolumn{2}{|l|}{ Explanatory variables } \\
\hline roa & Return over assets \\
\hline lnassets & Log of (1+assets) \\
\hline lnsales/assets & Log of (1+sales/as sets $)$ \\
\hline lndebt/assets & Log of (1+debt/assets $)$ \\
\hline sector 0 & Equals 1 if cannot be classified \\
\hline sector 1 & Equals 1 if activity is Agriculture,Fishing or Livestock \\
\hline sector 3 & Equals 1 if activity is Mining \\
\hline sector 4 & Equals 1 if activity is Industry \\
\hline sector 5 & Equals 1 if activity is Electricity,Water or Gas Production \\
\hline sector 6 & Equals 1 if activity is Construction \\
\hline sector 7 & Equals 1 if activity is Wholesale or Retail Distribution \\
\hline sector 8 & Equals 1 if activity is other Services \\
\hline situation 1 & Equals 1 if credit situation is 1 in marginal bank \\
\hline situation 2 & Equals 1 if credit situation is 2 in marginal bank \\
\hline situation 3 & Equals 1 if credit situation is 3 in marginal bank \\
\hline situation 4 & Equals 1 if credit situation is 4 in marginal bank \\
\hline situation 5 & Equals 1 if credit situation is 5 in marginal bank \\
\hline situation 6 & Equals 1 if credit situation is 6 in marginal bank \\
\hline lnbounced/liabilites & Log $(1+$ amount in bounced checks/liabilities in marginal bank) \\
\hline unwarranted/overdrafts & Percentage of unwarranted overdrafts over total overdrafts in marginal bank \\
\hline foreign bank $=1$ & Equals 1 if the marginal bank is foreign \\
\hline public bank=1 & Equals 1 if the marginal bank is public \\
\hline wholesale bank $=1$ & Equals 1 if the marginal bank is wholesale \\
\hline bank's market share & Share of the marginal bank's assets in the assets of the financial system \\
\hline liabilities bank/system & Percentage of liabilities in marginal bank over liabilities in system (excluding write-offs) \\
\hline no. bank & Number of banks with whom firm operates \\
\hline no. credit lines & Number of types of loans, unused credit lines and unquoted shares in marginal bank \\
\hline bounced other bank $=1$ & Equals 1 if firm has bounced checks in other banks \\
\hline system situation $(-1,0,1)$ & Equals 1 if median situation in system is larger ( i.e. worse), 0 if equal, -1 if smaller (i.e. better) \\
\hline no. bank square & Square of number of banks \\
\hline
\end{tabular}




\begin{tabular}{|c|c|}
\hline \multicolumn{2}{|r|}{ Variables - Quantity Regressions } \\
\hline \multicolumn{2}{|l|}{ Dependant variables } \\
\hline lndebt/assets & Log of (1+debt/assets) \\
\hline Inliabilities/a. & Log of (1+liabilities in main bank/assets) \\
\hline lnloan/a. & Log of (1+loans in main bank/assets $)$ \\
\hline lnoverdraft/a. & Log of (1+overdrafts in main bank/assets) \\
\hline contitotb & Percentage of unused credit lines over liabilities in main bank (excluding write-offs) \\
\hline \multicolumn{2}{|l|}{ Explanatory variables } \\
\hline roa & Return over assets \\
\hline lnassets & Log of (1+assets) \\
\hline Insales/assets & Log of (1+sales/assets) \\
\hline sector 0 & Equals 1 if cannot be classified \\
\hline sector 1 & Equals 1 if activity is Agriculture,Fishing or Livestock \\
\hline sector 3 & Equals 1 if activity is Mining \\
\hline sector 4 & Equals 1 if activity is Industry \\
\hline sector 5 & Equals 1 if activity is Electricity,Water or Gas Production \\
\hline sector 6 & Equals 1 if activity is Construction \\
\hline sector 7 & Equals 1 if activity is Wholesale or Retail Distribution \\
\hline sector 8 & Equals 1 if activity is other Services \\
\hline situation 1 & Equals 1 if credit situation is 1 in main bank \\
\hline situation 2 & Equals 1 if credit situation is 2 in main bank \\
\hline situation 3 & Equals 1 if credit situation is 3 in main bank \\
\hline situation 4 & Equals 1 if credit situation is 4 in main bank \\
\hline situation 5 & Equals 1 if credit situation is 5 in main bank \\
\hline situation 6 & Equals 1 if credit situation is 6 in main bank \\
\hline lnbounced/liabilites & $\log (1+$ amount in bounced checks/liabilities in main bank $)$ \\
\hline guarrantees/liabilities & Percentage of guarantees over liabilities in the main bank \\
\hline foreign bank $=1$ & Equals 1 if the main bank is foreign \\
\hline public bank $=1$ & Equals 1 if the main bank is public \\
\hline wholesale bank $=1$ & Equals 1 if the main bank is wholesale \\
\hline bank's market share & Share of the main bank's assets in the assets of the financial system \\
\hline liabilities bank/system & Percentage of liabilities in marginal bank over liabilities in system (excluding write-offs). \\
\hline no. banks & Number of banks with whom firm operates \\
\hline no. credit lines & Number of types of loans, unused credit lines, and unquoted shares in main bank \\
\hline bounced other bank=1 & Equals 1 if firm has bounced checks in other banks \\
\hline system situation $(-1,0,1)$ & Equals 1 if median situation in system is larger (i.e. worse), 0 if equal, -1 if smaller (i.e. better) \\
\hline no. bank square & Square of number of banks \\
\hline
\end{tabular}


E. Selection equations in Heckman two-step procedure

Table E.1

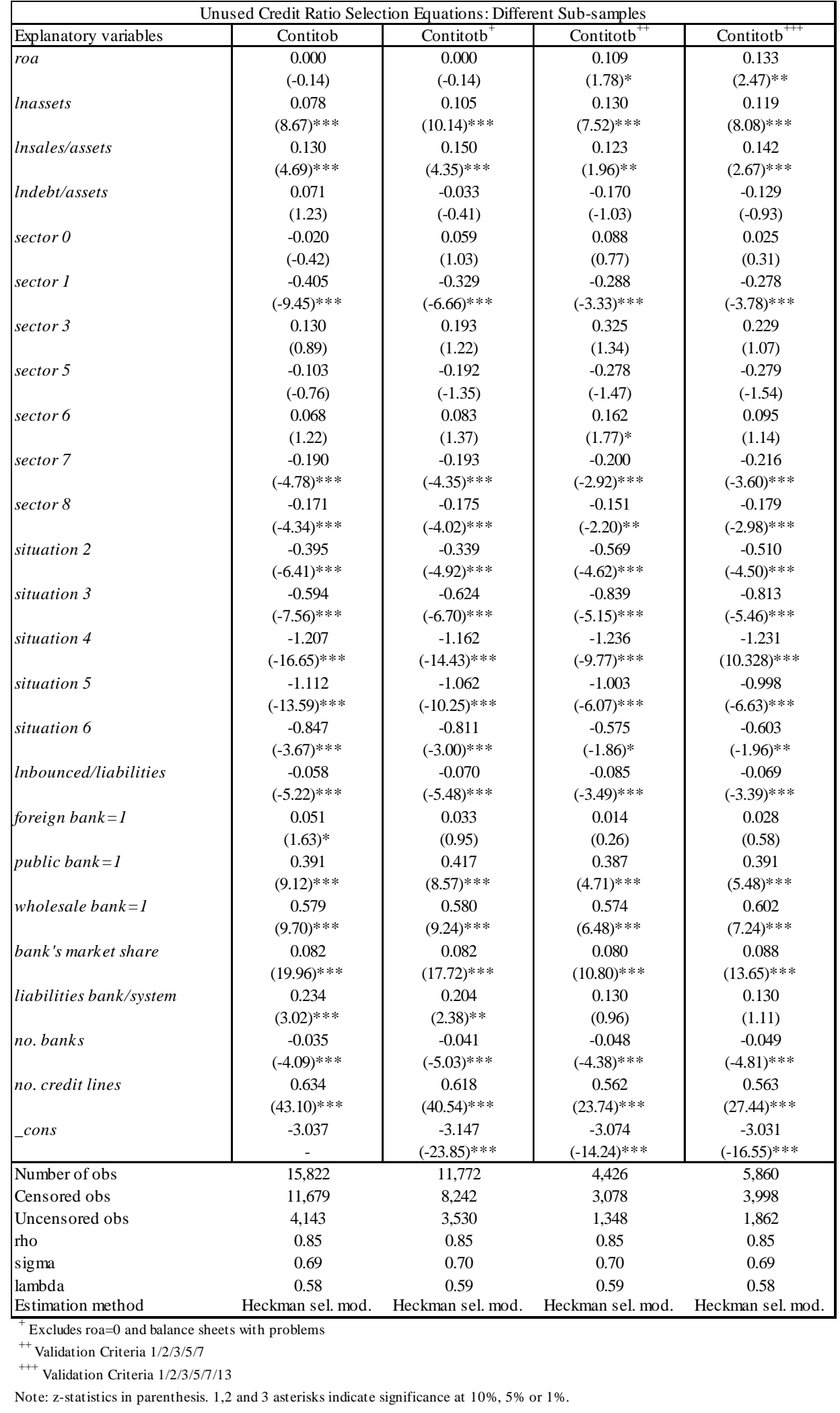


Table E.2

\begin{tabular}{|c|c|c|c|c|}
\hline \multicolumn{5}{|c|}{ Unused Credit Ratio Selection Equations: Additional Variables } \\
\hline Explanatory variables & Contitotb $^{+++}$ & Contitotb ${ }^{+++}$ & Contitotb ${ }^{+++}$ & Contitotb $^{+++}$ \\
\hline roa & $\begin{array}{c}0.133 \\
(2.47)^{* *}\end{array}$ & $\begin{array}{c}0.128 \\
(2.38)^{* *}\end{array}$ & $\begin{array}{c}0.140 \\
(2.58) * * *\end{array}$ & $\begin{array}{c}0.142 \\
(2.61)^{* * * *}\end{array}$ \\
\hline \multirow[t]{2}{*}{ lnassets } & 0.119 & 0.112 & 0.112 & 0.115 \\
\hline & $(8.08)^{* * *}$ & $(7.64) * * *$ & $(7.63)^{* * *}$ & $(7.75)^{* * *}$ \\
\hline \multirow[t]{2}{*}{ Insales/assets } & 0.142 & 0.139 & 0.135 & 0.136 \\
\hline & $(2.67)^{* * *}$ & $(2.61) * * *$ & $(2.54)^{* *}$ & $(2.56) * * *$ \\
\hline \multirow[t]{2}{*}{ lndebt/assets } & -0.129 & -0.121 & -0.120 & -0.112 \\
\hline & $(-0.93)$ & $(-0.87)$ & $(-0.86)$ & $(-0.81)$ \\
\hline \multirow[t]{2}{*}{ sector 0} & 0.025 & 0.021 & 0.015 & 0.012 \\
\hline & $(0.31)$ & $(0.25)$ & $(0.17)$ & (0.14) \\
\hline \multirow[t]{2}{*}{ sector 1} & -0.278 & -0.284 & -0.288 & -0.292 \\
\hline & $(-3.78)^{* * *}$ & $(-3.87)^{* * *}$ & $(-3.91)^{* * *}$ & $(-3.97) * * *$ \\
\hline \multirow[t]{2}{*}{ sector 3} & 0.229 & 0.235 & 0.244 & 0.248 \\
\hline & (1.07) & (1.10) & (1.13) & (1.15) \\
\hline \multirow[t]{2}{*}{ sector 5} & -0.279 & -0.273 & -0.276 & -0.273 \\
\hline & $(-1.54)$ & $(-1.50)$ & $(-1.52)$ & $(-1.50)$ \\
\hline \multirow[t]{2}{*}{ sector 6} & 0.095 & 0.116 & 0.116 & 0.119 \\
\hline & (1.14) & (1.39) & (1.39) & $(1.42)$ \\
\hline \multirow[t]{2}{*}{ sector 7} & -0.216 & -0.211 & -0.212 & -0.213 \\
\hline & $(-3.60)$ & $(-3.52)^{* * *}$ & $(-3.53)^{* * *}$ & $(-3.55) * * *$ \\
\hline \multirow[t]{2}{*}{ sector 8} & -0.179 & -0.171 & -0.174 & -0.179 \\
\hline & $(-2.98) * * *$ & $(-2.84)^{* * *}$ & $(-2.89)^{* * *}$ & $(-2.97) * * *$ \\
\hline \multirow[t]{2}{*}{ situation 2} & -0.510 & -0.476 & -0.611 & -0.612 \\
\hline & $(-4.50) * * *$ & $(-4.17)^{* * *}$ & $(-4.92)^{* * *}$ & $(-4.92) * * *$ \\
\hline \multirow[t]{2}{*}{ situation 3} & -0.813 & -0.753 & -0.838 & -0.833 \\
\hline & $(-5.46) * * *$ & $(-4.99) * * *$ & $(-5.36) * * *$ & $(-5.34) * * *$ \\
\hline \multirow[t]{2}{*}{ situation 4} & -1.231 & -1.132 & -1.163 & -1.155 \\
\hline & $(10.33)^{* * * *}$ & $(-9.38) * * *$ & $(-9.53) * * *$ & $(-9.45) * * *$ \\
\hline situation 5 & -0.998 & -0.953 & -1.038 & -1.039 \\
\hline & $(-6.63) * * *$ & $(-6.35)^{* * *}$ & $(-6.76)^{* * *}$ & $(-6.78) * * *$ \\
\hline situation 6 & -0.603 & -0.539 & -0.742 & -0.738 \\
\hline & $(-1.96)^{* *}$ & $(-1.753)^{*}$ & $(-2.35)^{* *}$ & $(-2.33)^{* *}$ \\
\hline Inbounced/liabilities & -0.069 & -0.049 & -0.043 & -0.044 \\
\hline & $(-3.39)^{* * *}$ & $(-2.33)^{* *}$ & $(-2.07)^{* *}$ & $(-2.10)^{* *}$ \\
\hline foreign bank $=1$ & 0.028 & 0.025 & 0.026 & 0.032 \\
\hline & $(0.58)$ & $(0.52)$ & $(0.54)$ & $(0.66)$ \\
\hline public bank $=1$ & 0.391 & 0.389 & 0.394 & 0.400 \\
\hline & $(5.48)^{* * *}$ & $(5.45)^{* * *}$ & $(5.50)^{* *}$ & $(5.58)^{* * *}$ \\
\hline wholesale bank $=1$ & 0.602 & 0.610 & 0.607 & 0.611 \\
\hline & $(7.24)^{* * *}$ & $(7.33) * * *$ & $(7.30)^{* * *}$ & $(7.34)^{* * *}$ \\
\hline bank's market share & 0.088 & 0.088 & 0.088 & 0.088 \\
\hline & $(13.65)^{* * *}$ & $(13.63)^{* * *}$ & $(13.57)^{* * *}$ & $(13.53)^{* * *}$ \\
\hline liabilities bank/system & 0.130 & 0.109 & 0.114 & 0.015 \\
\hline & $(1.11)$ & $(0.93)$ & $(0.97)$ & $(0.12)$ \\
\hline no. banks & -0.049 & -0.046 & -0.046 & -0.081 \\
\hline & $(-4.81)^{* * *}$ & $(-4.53)^{* * *}$ & $(-4.51)^{* * *}$ & $(-3.54)^{* * *}$ \\
\hline no. credit lines & 0.563 & 0.564 & 0.564 & 0.568 \\
\hline & $(27.44)^{* * *}$ & $(27.42)^{* * *}$ & $(27.375)^{* * *}$ & $(27.40)^{* * *}$ \\
\hline _cons & -3.031 & -2.961 & -2.957 & -2.833 \\
\hline & $(-16.55)^{* * *}$ & $(-16.11)^{* * *}$ & $(-16.06)^{* * *}$ & $(14.30)^{* * *}$ \\
\hline bounced other bank $=1$ & - & -0.284 & -0.286 & -0.279 \\
\hline & - & $(-4.00)^{* * *}$ & $(-4.01)^{* * *}$ & $(-3.90) * * *$ \\
\hline system situation $(-1,0,1)$ & - & - & -0.255 & -0.259 \\
\hline & - & - & $(-3.02)^{* * *}$ & $(-3.07)^{* * *}$ \\
\hline no banks square & - & - & - & 0.002 \\
\hline & - & - & - & $(1.72)^{*}$ \\
\hline Number of observations & 5,860 & 5,860 & 5,860 & 5,860 \\
\hline Censored obs & 3,998 & 3,998 & 3,998 & 3,998 \\
\hline Uncensored obs & 1,862 & 1,862 & 1,862 & 1,862 \\
\hline rho & 0.85 & 0.85 & 0.85 & 0.85 \\
\hline sigma & 0.69 & 0.68 & 0.69 & 0.67 \\
\hline lambda & 0.58 & 0.58 & 0.58 & 0.57 \\
\hline Estimation method & Heckman sel. moc & Heckman sel. mo & Heckman sel. mo & Heckman sel. mod. \\
\hline
\end{tabular}

